\title{
Biochar-A Panacea for Agriculture or Just Carbon?
}

\author{
Elvir Tenic ${ }^{\dagger}$, Rishikesh Ghogare $^{\dagger}$ and Amit Dhingra $*$ (D) \\ Department of Horticulture, Washington State University, Pullman, WA 99164, USA; elvir.tenic@wsu.edu (E.T.); \\ rishikesh.ghogare@wsu.edu (R.G.) \\ * Correspondence: adhingra@wsu.edu \\ † These authors contributed equally to this work.
}

Received: 18 May 2020; Accepted: 29 June 2020; Published: 3 July 2020

Abstract: The sustainable production of food faces formidable challenges. Foremost is the availability of arable soils, which have been ravaged by the overuse of fertilizers and detrimental soil management techniques. The maintenance of soil quality and reclamation of marginal soils are urgent priorities. The use of biochar, a carbon-rich, porous material thought to improve various soil properties, is gaining interest. Biochar (BC) is produced through the thermochemical decomposition of organic matter in a process known as pyrolysis. Importantly, the source of organic material, or 'feedstock', used in this process and different parameters of pyrolysis determine the chemical and physical properties of biochar. The incorporation of BC impacts soil-water relations and soil health, and it has been shown to have an overall positive impact on crop yield; however, pre-existing physical, chemical, and biological soil properties influence the outcome. The effects of long-term field application of $\mathrm{BC}$ and how it influences the soil microcosm also need to be understood. This literature review, including a focused meta-analysis, summarizes the key outcomes of BC studies and identifies critical research areas for future investigations. This knowledge will facilitate the predictable enhancement of crop productivity and meaningful carbon sequestration.

Keywords: agronomy; sustainability; organic fertilizer; crop productivity; soil acidification; soil organic matter; pyrolysis; microbial activity

\section{Introduction}

"If you desire peace, cultivate justice, but at the same time cultivate the fields to produce more bread; otherwise there will be no peace" Norman Borlaug, Oslo, Norway, December 11, 1970. Nobel lecture.

What was prevalent in the 1960s holds true yet again - the world stands at a threshold where the availability of food is threatened, albeit for reasons different than six decades ago. The changing climate, deteriorating land and water conditions, and loss of biodiversity present unprecedented challenges for humankind [1]. At present, greenhouse gas (GHG) emissions are increasing rapidly, with carbon dioxide $\left(\mathrm{CO}_{2}\right)$ levels rising more than 3\% annually since the 2000s. These GHG discharges have a drastic impact on the climate, despite global efforts to reduce the emissions over the last few decades [2]. As a step toward reducing GHG emissions, more than 100 countries signed and ratified the Paris Climate Agreement, aiming to limit the increase in global temperature to $1.5-2{ }^{\circ} \mathrm{C}$ over the next 30 years [3]. The achievement of this target requires the swift adoption of carbon-neutral and carbon-negative technologies to limit the global GHG emissions to approximately 9.8 gigatons of carbon $[4,5]$. Several approaches are being considered for $\mathrm{CO}_{2}$ removal from the atmosphere, such as the adoption of bioenergy, direct carbon capture, afforestation and reforestation, the modification of agricultural practices, the use of bioenergy, and the direct infusion of recalcitrant carbon into the soil using biochar (BC) [6-9]. The longer-term sequestration of carbon into the soil using biochar is one of the potential carbon-negative approaches. As soils store twice as much carbon compared 
to atmospheric reserves and for longer periods, it has been hypothesized that increasing global soil organic matter stocks by 4 per 1000 (or 0.4\%) per year in agricultural land can offset 30\% of global greenhouse emission [4].

The agricultural and industrial revolutions, combined with unsustainable farming practices, have significantly affected global soil health. This is mainly a consequence of the type of fertilizer used in crop production. Earlier practices of using manure and compost replenished the soil organic matter (SOM) on a regular basis. However, the use of petroleum-derived chemical fertilizers is detrimental to SOM as they enhance the accumulation of salt and reduce microbial diversity. Fertilizers derived from the Haber-Bosch process contribute to more than $1 \%$ of total global $\mathrm{CO}_{2}$ emissions [10,11]. Soil health has further declined with the gradual acidification of arable lands and continual soil erosion negatively affecting crop yields throughout the world. While the use of compost and manure to enhance and maintain SOM is an option, it presents limitations due to the accumulation of organic pollutants, increased pathogen pressure, and leaching of excess nutrients into waterways, leading to eutrophication $[12,13]$.

There is a long history of enriching soils with recalcitrant carbon practiced by indigenous farmers in different parts of the world. Black-earth-like anthropogenic soils known as 'Terra Preta' have been discovered in several regions of South America and Japan. These dark soils were amended with charcoal-like substances, generally referred to as biochar (BC), and possibly other amendments such as manure, which conferred enhanced fertility to the soil [14,15]. Chemical analysis revealed that the BC-treated areas contained 70 times more carbon than the surrounding soils, demonstrating its long half-life [16]. The enhanced fertility of these soils most likely resulted from increased SOM, higher $\mathrm{pH}$, higher water-holding capacity, and high nutrient-holding capacity [16-18]. Due to the potential advantages of 'Terra Preta', several global efforts are afoot to recreate such soils. Biochar represents an organic soil amendment that improves soil quality for agricultural production [19].

There are various studies reporting the impact of BC on plant growth and development; however, the results have remained inconsistent [20]. There are several types of biochar, produced using various pyrolysis parameters and feedstocks. A standardized biochar with predictable physical, biological, and chemical properties, which is beneficial to plant growth and development, remains to be developed [21]. Furthermore, a positive impact on growth and development does not directly translate to improved yields. In fact, there are reports indicating that enhanced growth and development compromises the plant defense systems. Therefore, this review discusses and summarizes the various aspects of how biochar impacts soil quality and crop productivity. The discussion concludes with a summary of some of the areas that need to be addressed to enable the widespread use of biochar in environmental, economic, agricultural, and ecological contexts.

\section{Biochar and Soil}

\subsection{Biochar}

Biochar (BC) is a carbon (C)-rich, porous material produced during the process of pyrolysis, which involves the thermochemical decomposition of organic matter in an oxygen-limited environment. Any feedstock, such as forest residue, agricultural by-products, and waste biomass can be converted into liquid fuels, gasses, and BC. The properties and yields of BC are highly variable depending on the rate of pyrolysis (fast/slow), feedstock, pyrolysis temperature, and retention time. Generally, slow pyrolysis with a heating rate of $5-20{ }^{\circ} \mathrm{C}$ per minute with higher residence time results in higher $\mathrm{BC}$ yield [22,23]. Fast pyrolysis with a higher heating rate $\left(>100{ }^{\circ} \mathrm{C} / \mathrm{min}\right)$ and lower residence time results in a higher yield of liquid fuel and reduced BC output [24]. Due to the complex nature of pyrolysis and diversity of feedstock, the final chemical and physical properties of BC vary. For example, a recent meta-analysis concluded that BC produced at higher temperature $\left(600-699^{\circ} \mathrm{C}\right)$ had a higher $\mathrm{pH}$ of approximately 9 compared to BC produced at lower temperatures (300-399 ${ }^{\circ} \mathrm{C}$ ) with an approximate $\mathrm{pH}$ of 5 [25]. This observation was supported by another recent meta-analysis [26]. The higher reaction 
temperatures reduce the amount of aliphatic carbons, oxygenated functional groups, cation exchange capacity (CEC), and total content of $\mathrm{N}, \mathrm{H}$, and $\mathrm{O}$. However, a higher temperature of production resulted in increased $\mathrm{pH}$, amount of $C$ fixed, total ash content, total $C$, and surface area of $B C[25,27,28]$. Ultimately, the bulk property and surface characteristics of any BC is determined by the feedstock source along with the pyrolysis parameters [23,29]. There remains a critical need to understand the characteristics of BCs produced from different feedstock, pyrolysis parameters, and the resulting relative impact on soil. In the following sections, recent research on $\mathrm{BC}$ s has been collated, and the effects of various BC regimens on soil physical properties, soil-water relations, soil organic matter, microbial activity, soil tilth and nutrient status, $\mathrm{pH}$, crop productivity, biotic stresses, and abiotic stresses have been discussed.

\subsection{Impact of Biochar on Soil}

\section{Physical Properties}

Physical properties of soil, such as bulk density, porosity, and water retention are important variables that impact plant growth and development. Human intervention in agricultural practices causes soil compaction, which is one of the key factors affecting plant growth [30]. Soil texture also plays a key role. Soil compaction above $1.7 \mathrm{~g} \mathrm{~cm}^{-3}$ results in restricted root growth and limits access to water and nutrients [31]. As a consequence, the yields of many crops such as soybean and corn have been shown to be negatively impacted [32,33]. The threshold bulk density for impact on root growth varies, with clayey soils having a lower bulk density threshold.

Amending soils with biochar increases soil porosity while decreasing soil bulk density, which aids in the transport of water, nutrients, and gases. These alterations encourage root formation and increased microbial respiration [26].

A meta-analysis reported that the addition of BC to soil reduced the bulk density of the soil by an average of $7.6 \%$ and increased its water-holding capacity and porosity by $15.1 \%$ and $8.4 \%$, respectively [34]. Similar results were reported in another meta-analysis where the average bulk density was decreased by $12 \%$ [35]. Fifteen of the 17 studies conducted in 2019 reported that biochar effectively reduced soil bulk density and increased the porosity and available water content (Table 1). However, there were two studies that reported either no effect on bulk density after the addition of $\mathrm{BC}$ [36] or an insignificant decrease [37]. It was also observed that a larger average BC particle size was more effective in reducing the bulk density of sandy loam soil than sandy soil [38]. In the case of sandy soil, bulk density significantly decreased and water-holding capacity was significantly increased with the addition of $\mathrm{BC}$ with small particle size [38]. A majority of the recent studies used biochar produced from agricultural residue and woody residue. Generally, a positive effect on the physical properties of soil was reported (Table 1). 
Table 1. A summary of recent studies related to the impact of biochar on physical properties of soil. The soil types listed in this table correspond to the types reported in the original publication. The usage of term 'slightly' in any of the categories indicates a change in mean values. BC: biochar.

\begin{tabular}{|c|c|c|c|c|c|c|c|c|}
\hline Exp. Type & BC Feedstock & Pyrolysis Temp. $\left({ }^{\circ} \mathrm{C}\right)$ & Soil Type & Bulk Density & Available Water Content & Total Porosity & BC Application Rates & Ref. \\
\hline \multirow[t]{2}{*}{$\mathrm{Lab}$} & \multirow[t]{2}{*}{ Agricultural residues } & \multirow[t]{2}{*}{450} & Loamy & Slightly decreased & $\begin{array}{c}\text { Slightly } \\
\text { increased }\end{array}$ & Increased & \multirow[t]{2}{*}{$0.46 \%(\mathrm{~W} / \mathrm{W})$} & \multirow[t]{2}{*}{ [37] } \\
\hline & & & Sandy & Slightly decreased & Slightly increased & Increased & & \\
\hline \multirow{2}{*}{$\mathrm{Lab}$} & \multirow{2}{*}{ Woody residues } & \multirow{2}{*}{620} & Sandy loam & Decreased & Increased & \multirow{2}{*}{ N/A } & \multirow{2}{*}{$1 \%, 5 \%, 10 \%$ and $20 \%(\mathrm{~V} / \mathrm{V})$} & \multirow{2}{*}{ [38] } \\
\hline & & & Sandy & Decreased & Increased & & & \\
\hline Field & N/A & N/A & N/A & Decreased & Increased & Increased & 5 and 10 tons $\mathrm{ha}^{-1}$ & [39] \\
\hline Field & Sewage sludge & $700-850$ & Loamy sand & Decreased & N/A & N/A & 20,40 , and 60 tons ha ${ }^{-1}$ & [40] \\
\hline \multirow{2}{*}{$\mathrm{Lab}$} & \multirow{2}{*}{ Agricultural residues } & \multirow{2}{*}{450} & Sandy loam & Decreased & No effect & Increased & \multirow{2}{*}{27.5 tons ha ${ }^{-1}$} & \multirow{2}{*}{ [41] } \\
\hline & & & Clay loam & Decreased & Increased & Increased & & \\
\hline Field & Agricultural residues & $200-600$ & Loam sand & Decreased & N/A & Increased & 10,25 , and 50 tons ha ${ }^{-1}$ & [42] \\
\hline Field & Agricultural residues & 360 & Sandy loam & Decreased & N/A & Increased & 4.5 and 9 tons ha ${ }^{-1}$ & [43] \\
\hline Lab & Agricultural residues & 300 and 700 & Desert & Decreased & Increased & Increased & $5 \%(\mathrm{~W} / \mathrm{W})$ & [44] \\
\hline Field & Woody residues & N/A & N/A & Decreased & Increased & Increased & 55 tons ha $^{-1}$ & [45] \\
\hline $\mathrm{Lab}$ & Agricultural residues & $350-650$ & Sandy & N/A & Increased & N/A & $1 \%, 2 \%, 3 \%$, and $4 \%(\mathrm{~W} / \mathrm{W})$ & [46] \\
\hline Lab & Woody residues & 350 & Sandy loam & Decreased & Increased & Increased & $2 \%, 4 \%$, and $6 \%(\mathrm{~W} / \mathrm{W})$ & [47] \\
\hline Field & Woody residues & 500 & Silt loam & Decreased & Increased & Increased & 24 and 46 tons $\mathrm{ha}^{-1}$ & [48] \\
\hline Field & Agricultural residues & $550-600$ & Clay loam & Decreased & $\mathrm{N} / \mathrm{A}$ & Increased & 10,20 , and 30 tons ha ${ }^{-1}$ & [49] \\
\hline Yard & Agricultural residues & $400-450$ & Planosol & Decreased & Increased & Increased & $1 \%, 2 \%$, and $3 \%(\mathrm{~W} / \mathrm{W})$ & [50] \\
\hline Field & Agricultural residues & 550 & Haplic Luvisol & Decreased & Increased & Increased & 10 and 20 tons $\mathrm{ha}^{-1}$ & [51] \\
\hline Lab & Forest residue & 450 & Desert sandy & Decreased & Increased & Increased & $39.5,58.7$, and 65 tons ha ${ }^{-1}$ & [52] \\
\hline Field & Agricultural residues & 550 & Sandy clay loam & No difference & Decreased & No difference & $5.5,16.5$, and 33 tons $\mathrm{ha}^{-1}$ & [36] \\
\hline Field & Woody residues & 580 & Luvisol & Decreased & Increased & Increased & 25- and 50-tons ha ${ }^{-1}$ & [53] \\
\hline
\end{tabular}


A most recent meta-analysis showed an average increase in soil porosity by $6.27 \%$, decrease in bulk density by $7.47 \%$, and increase in water-holding capacity by $9.82 \%$ [54]. However, biochar derived from softwood and walnut shell did not affect soil porosity or water retention over a period of six years in silty clay soil. It was suggested that the effect on soil porosity and water retention was temporary until the pores of biochar were occluded with clay or soil organic matter (SOM) [55]. Woody biomass derived-biochar was shown to have no effect on soil porosity or water retention after four years of amendment [56].

Comparably, in the case of soil bulk density, a majority of the studies reported a decrease after BC amendment $[34,35,54]$. There were also a few reports where no significant decrease in bulk density was observed [57-60]. A majority of the data from previous meta-analyses and reports indicate that the addition of $B C$ to a coarse, textured soil had a larger positive impact on soil physical properties compared to clay textured soil $[34,35,54,61,62]$.

Biochar produced from wheat straw $\left(550-600{ }^{\circ} \mathrm{C}\right)$ incorporated with clay loamy soil improved its physical properties and enhanced the yield of wheat when irrigated with saline water [49]. The biochar amendment decreased soil bulk density by $5.5-11.6 \%$ and increased porosity by $35.4-49.5 \%$. The biochar amendment also seemed to mitigate soil sodicity and also increased total NPK (nitrogen, phosphorous, potassium) availability in mixed soil layer. This resulted in the improvement of wheat yield by $8.6 \%$ and $8.4 \%$ at the $\mathrm{BC}$ application rates of 10 and $20 \mathrm{t} / \mathrm{ha}$, respectively [49]. However, at the application rate of $30 \mathrm{t} / \mathrm{ha}^{-1}$, the improvement in yield was the lowest $(2.2 \%)$, which was probably due to high salinity and the immobilization of $\mathrm{N}$. This study suggests that for saline irrigation in clay loamy soil, the optimal application rate of BC produced from agricultural residue should be between 10 and 20 tha $^{-1}$ [49]. These studies imply that initial soil characteristics, along with BC application rate and type, determine the final changes in the physical properties of the soil.

\subsection{Soil-Water Relations}

Accessible fresh water supplies are becoming increasingly limited, and 70\% of available fresh water supports crop irrigation [63]. Although biochar holds promise for improved hydrological functions, there are differing schools of thought regarding the role of $\mathrm{BC}$ in improving the long- term water-holding capacity of soil [64]. BC amendment has been reported to increase rainfall absorption and soil water-holding capacity, particularly in non-irrigated production regions [65-67]. However, the pre-existing physical and biochemical characteristics of the soil and the wide array of $\mathrm{BC}$ production parameters (feedstock inputs, pyrolysis temperatures, application methods, and geographical variables) ultimately determine the $\mathrm{BC}^{\prime} \mathrm{s}$ impact on water-holding capacity. In order to probe the influence of $\mathrm{BC}$ on water dynamics, initial experiments were performed with soil columns in greenhouses with the addition of farm or potting soils. Field studies are now becoming prevalent in peer-reviewed literature, particularly within the last 10 years.

The identification of key features that contribute to improved water retention could lead to an expanded role for $\mathrm{BC}$ in crop production. Overall, it was determined that feedstock selection and pyrolysis temperature, the most predictive variables impacting water status, impact BC surface chemistry and porosity, the latter of which is a major contributor to the water-holding capacity of BC $[68,69]$. Pore saturation is highly dependent on BC surface chemistry, which is affected by pyrolysis temperature. An increase in pyrolysis temperature volatilizes organic elements and thermally cracks the biomass, thereby rendering hydrophobic compounds more hydrophilic and increasing the overall BC porosity [70]. Conversely, BCs produced via low-temperature pyrolysis exhibit negative capillary pressure, inhibiting the hydration of the pore space [71].

Comparative analysis of Fourier transform infrared (FTIR) spectroscopy data collected from nine different feedstocks pyrolyzed at $250{ }^{\circ} \mathrm{C}, 500{ }^{\circ} \mathrm{C}$, and $700{ }^{\circ} \mathrm{C}$ revealed the relationship between $\mathrm{BC}$ surface chemistry and hydrophobicity [72]. The spectrometer data indicated that the functional group $\mathrm{C}=\mathrm{O}$ in carboxylic acid was present only in the $\mathrm{BC}$ obtained from pyrolysis at $250{ }^{\circ} \mathrm{C}$, making it hydrophobic. $\mathrm{BC}$ produced at $500{ }^{\circ} \mathrm{C}$ and $700{ }^{\circ} \mathrm{C}$ were deemed more appropriate for improving soil 
water status. A significant correlation was identified between low pyrolysis temperature $\left(<300^{\circ} \mathrm{C}\right)$ and surface functional groups (specifically acidic moieties), and increased hydrophobicity contributing to low water retention was reported $[68,73]$. Other factors, including cation exchange capacity, play a role along with the variables of surface groups and porosity in determining the hydrophobic properties for each specific BC [74].

Considerable variation in total pore volumes was reported in BCs produced at $400{ }^{\circ} \mathrm{C}, 600{ }^{\circ} \mathrm{C}$, and $800{ }^{\circ} \mathrm{C}$ from various feedstocks. Wood-based BC possessed a comparatively higher range of micropores $(5-30 \mu \mathrm{m})$, and although the number of micropores decreased with increasing pyrolysis temperatures, this BC still retained relatively large pore volumes overall due to pyrogenic micropores. In contrast, the pore volumes of BC derived from poultry manure and agricultural wastewater sludge were smaller, indicating that these feedstocks may not be suitable for improving water retention in amended soils [75]. While BC amendment imparts large increases in porosity, permeability, and moisture retention in clay soils, these affects are diminished in silt loam soils [76,77]. The particle size of BC had a clear impact on soil bulk density, with a linear decrease in bulk density of sandy soil observed when large-particle-containing hardwood BC $\left(620^{\circ} \mathrm{C}\right)$ was used. Smaller BC particles increased water-holding capacity compared to larger BC particles [38], which was possibly due to the increased microporosity resulting from higher pyrolysis temperatures. Despite this, the addition of $\mathrm{BC}$ at $25 \mathrm{Mg} \mathrm{ha}^{-1}$ to sandy soils did not result in increased water retention. In a study with Miscanthus giganteus residue-derived BC $\left(450{ }^{\circ} \mathrm{C}\right)$, the increased porosity of larger BC particles proved beneficial for soil water retention, while smaller BC particles under $0.15 \mathrm{~mm}$ retained water too well, thereby strongly reducing its bioavailability [37].

BC was reported to increase the water-holding capacity in coarse and medium textured soils by an average of $51 \%$ and $13 \%$, respectively [78]. This was attributed to a higher abundance of soil micropores resulting from the intrinsic microporosity of BC. However, a reduction in water-holding capacity was reported in fine-textured soils, which was possibly due to the overall decrease in micropores or occlusion of existing pores. Field studies of high-porosity BCs derived from softwood $\left(600-700^{\circ} \mathrm{C}\right)$ and walnut shell $\left(900^{\circ} \mathrm{C}\right)$ reported a temporary improvement of water-holding capacity; however, no long-term improvement was seen in BC-amended silty clay loam soils subjected to a corn-tomato rotation with conventional or organic production regimes [55]. Plant-available water in fine-textured soils could be enhanced through the management or manipulation of hydrophobic properties of BC, thereby improving BC-soil interactions [78]. For example, it has been reported that grapevine feedstocks subjected to low pyrolysis temperatures (approximately $400{ }^{\circ} \mathrm{C}$ ) yield $\mathrm{BC}$ with a $23 \%$ higher available water content in clay soils [79].

\subsection{Soil Tilth and Nutrient Status}

Defining management approaches to increase the productivity of agricultural soils remains a priority as food demand increases and arable farmland decreases [80]. As a mineral-rich organic material, BC can be incorporated into agricultural soils, potentially serving as a slow-releasing fertilizer, positively affecting soil tilth and enhancing the nutrient status of agricultural soils [81-83]. The basis for this potential use lies in the unique porosity of $\mathrm{BC}$, its facilitation of chemical and physical interactions between nutrients and the carbon material, and its strong intrinsic sorption properties. Due to the large surface area, porous microstructures, and negative surface charge, BC enhances nutrient retention in the soil. Furthermore, the nutrient retention properties of BC may significantly reduce irrigation or the rainfall-induced leaching of water-soluble minerals [66,84]. The slow desorption of the BC-sequestered nutrient elements may supply a steady rate of nutrient delivery, thereby alleviating the need for excessive fertilizer use. Together, these agronomic benefits to soil health may also mitigate freshwater eutrophication that results from fertilizer runoff, prevent pesticide contamination, and reduce the risk of environmental damage [85-87].

While composition varies based on feedstock and pyrolysis parameters, a universal characteristic of $\mathrm{BC}$ is that it is carbon-dense, which facilitates the retention of necessary plant nutrients such as $\mathrm{N}, \mathrm{P}$, 
$\mathrm{K}, \mathrm{Mg}, \mathrm{Fe}$, and Ca [88-91]. Depending on the soil status and existing nutrient deficiencies, BCs can be custom-manufactured to replenish depleted nutrients. It has been demonstrated that $\mathrm{BC}$ s derived from different feedstocks possess variable amounts of beneficial plant nutrients $[47,66,91-94]$. The general characteristics of three major BC feedstock sources are as follows:

- Organic waste feedstocks, such as animal manure and sewage sludge-derived BC, are rich in potassium and phosphorus, low in C levels, and low in surface area; additionally, eggshell-derived $\mathrm{BC}$ is elevated in calcium levels

- Wood-based BC is high in organic matter and surface area, while low in CEC and N, P, and K levels

- Crop residue-derived $B C$ properties reside somewhere in between those of the two previous categories, with specific crops producing $B C$ with different properties (e.g., wheat and rice $B C$ is high in silicon content; soybean BC is high in N).

These feedstocks can be blended in appropriate ratios to produce BCs with desired nutrient and/or mineral profiles. Further modifications, including the alteration of pyrolysis parameters, physical alterations, chemical modifications, and BC-mediated composting have been discussed to aid in the customization of BC to ameliorate detrimental soil aspects [91].

Soil $\mathrm{pH}$ and the abundance/availability of important plant nutrients such as phosphorus $(\mathrm{P})$ and nitrogen $(\mathrm{N})$ are positively affected in $\mathrm{BC}$-amended soils. Limiting the pyrolysis temperatures to less than $700{ }^{\circ} \mathrm{C}$ enhances the levels of $\mathrm{P}$ and $\mathrm{N}$ in $\mathrm{BC}$, both of which can be lost at higher temperatures due to the volatilization and transformation of $\mathrm{NH}_{4}{ }^{+}$to heterocyclic-N [92]. Wood-derived $\mathrm{BC}\left(450-550{ }^{\circ} \mathrm{C}\right)$ applied at $20 \mathrm{t} /$ ha significantly improved the bioavailability of $\mathrm{P}$ in sandy soils, which is an effect that was primarily attributed to the perturbation of abiotic processes (adsorption/desorption of $\mathrm{P}$, altered redox potentials, development of organomineral aggregations) [95]. BC nitrogen levels are correlated closely with the original source of the char; feedstocks high protein biomass, such as grasses, generate BCs with higher $\mathrm{N}$ levels (approximately $10 \%$ by weight), while wood-derived $\mathrm{BC}$ s tend to be $\mathrm{N}$-poor (approximately $1 \%$ by weight) [92]. While several individual studies show that wheat $\mathrm{BC}\left(450{ }^{\circ} \mathrm{C}\right)$ applications increased total soil $\mathrm{N}$ [96], other studies found significant decreases of soil $\mathrm{NH}_{4}{ }^{+}$and $\mathrm{NO}_{3}{ }^{-}$following $\mathrm{BC}$ addition. The latter outcome was likely due to the inherent recalcitrance of the small amount of extractable inorganic $\mathrm{N}$ and organic $\mathrm{N}$ present. In the studies reporting increased $\mathrm{N}$, this increase could be attributed to a heightened abundance of recruited microorganisms, which assist in the degradation of soil organic nitrogen [97].

In addition to improving mineral nutrient retention, $\mathrm{BC}$ has a role in the amelioration of soil erosion and the improvement of overall soil structure [98,99]. A study utilizing hardwood $\left(600{ }^{\circ} \mathrm{C}\right)$ $\mathrm{BC}$ at 15 and $30 \mathrm{t} /$ ha concentrations to amend clay-rich soils in incubation containers demonstrated improved soil aggregate structure and soil stabilization [100]. This is likely due to the interaction of carboxylic and phenolic functional groups on the $\mathrm{BC}$ surface, resulting in the formation of cation bridges and consequent BC-mineral complexes [101]. For example, microaggregates observed to form upon the incorporation of hardwood-derived $\mathrm{BC}\left(700^{\circ} \mathrm{C}\right)$ into soil with application rates of $2.5 \%$ or $5 \%$ correlated with a 50-64\% decrease in soil loss, respectively [102]. An additional study with oak wood-derived $\mathrm{BC}$ applied at a rate of $10 \mathrm{Mg}$ /ha provided further evidence for the stabilizing effects of $\mathrm{BC}$, with significant decreases in soil loss of almost $20 \%$ observed in a simulated rainfall experiment. In addition to improving soil retention, $\mathrm{BC}$ appeared to reduce the impact force from rainfall, thereby facilitating the reduction of particle detachment [103].

\subsection{Soil Acidification}

The expanding global incidence of soil acidification is concerning, with acidic soils $(\mathrm{pH}<5.5)$ currently accounting for approximately $50 \%$ of arable land [104,105]. The excessively low $\mathrm{pH}$ of acidic soil results in reduced productivity and decreased crop fertility. The main causes of soil acidification include the use of ammonia-based fertilizers and low nitrogen-use efficiency. In soil, ammonia fertilizers are converted to nitrates and hydrogen ions. The hydrogen ions that are left 
over following the uptake of nitrates by crops or after nitrate leaching increase the soil acidity [106]. The removal of crop residue also accelerates soil acidification. An excessive reduction of $\mathrm{pH}$ leads to the increased solubility of soil-bound aluminum; thus, soil acidification generally leads to aluminum (Al) toxicity [105]. Aluminum toxicity, in turn, leads to deficiencies in phosphorus, calcium, magnesium, and potassium cations and contributes to impaired root growth.

Current strategies to alleviate soil acidification include liming, the application of crop residue, and the use of industrial products; however, these methods have several disadvantages. For example, liming material elicits a disproportionately strong effect on top surface soils in comparison with lower layers. This method is also costly, due to the high transportation costs of liming material [106,107]. The application of industrial products can lead to heavy metal toxicity [108]. Similarly, the excessive application of organic material may lead to both heavy metal accumulation and eutrophication, the latter resulting from augmented concentrations of nitrogen and phosphorus [26,109]. Hence, biochar, which is naturally alkaline, is a potential solution to the problem of soil acidity.

Various studies have validated the effectiveness of BC in reducing soil acidity [110-112], and a linear correlation of biochar alkalinity with the resulting soil $\mathrm{pH}$ has been established [105]. Furthermore, it has been demonstrated that the increased $\mathrm{pH}$-buffering capacity of BC-amended soils is due to a BC-derived increase in cation exchange capacity [113]. The carbonates and oxides of cations such as $\mathrm{Ca}, \mathrm{K}, \mathrm{Mg}, \mathrm{Na}$, and $\mathrm{Si}$ formed during pyrolysis are known to react with dissolved $\mathrm{Al}$ and hydrogen ions in soil, leading to increased soil $\mathrm{pH}$ and decreased Al uptake by the plants [114]. Previous meta-analyses and individual studies have concluded that in imparting increased buffering capacity, BC amendment can increase the soil $\mathrm{pH}$ by $>2.0$ units [115]. Not surprisingly, the original feedstock material plays a key role in determining the final $\mathrm{pH}$ of $\mathrm{BC}$. For example, $\mathrm{BC}$ generated from manure has higher alkalinity, $\mathrm{pH}$-buffering capacity, and propensity for the alleviation of $\mathrm{Al}$ toxicity, compared to crop residue-derived BC. Thus, the former would be more suitable for extremely acidic soils [116]. Soils exhibiting Al toxicity could be reclaimed via BC amendment, the ash content of which would precipitate $\mathrm{Al}_{3}{ }^{+}$to less toxic $\mathrm{Al}(\mathrm{OH})_{3}$ and $\mathrm{Al}(\mathrm{OH})_{4}$ [117]. Furthermore, carboxyl and other organic functional groups on the $\mathrm{BC}$ surface would provide additional sites for $\mathrm{Al}_{3}{ }^{+}$binding [117]. Functional groups such as $\mathrm{COO}^{-}$and $\mathrm{O}^{-}$also contribute to the alkalinity of biochar through reaction with free $\mathrm{H}^{+}$ions $[27,118]$.

In soil, $\mathrm{H}^{+}$is produced through the aerobic conversion of ammonia to nitrate. Experimental results have demonstrated that $\mathrm{BC}$ amendment leads to decreased soil nitrification through the adsorption of $\mathrm{NH}_{3}$ and $\mathrm{NH}_{4}$ onto the $\mathrm{BC}$ surface. Soil amendment with wheat straw-derived $\mathrm{BC}\left(500{ }^{\circ} \mathrm{C}\right)$ led to reduced nitrification in cadmium-contaminated Ferralsol soil by decreasing soil acidity (Table 2) [119]. Similarly, amendment with pig manure-derived BC $\left(300^{\circ} \mathrm{C}\right)$ resulted in decreased soil acidification and increased cation exchange capacity $[120,121]$, and crop residue-derived BC $\left(500{ }^{\circ} \mathrm{C}\right)$ led to improved rice growth, yield, and soil nutrient availability in acidified soil [122]. Collectively, information from the literature has established that carbon content, nutrient availability, and alkalinity are highest when BC is generated from manure feedstock, intermediate when generated from crop residue feedstock, and lowest when generated from woody plants-based feedstock (Table 2). Finally, biochar produced at higher temperature has higher $\mathrm{pH}$ and might be more suitable for countering soil acidity. 
Table 2. Selected recent studies documenting the impact of biochar on acidified soils.

\begin{tabular}{|c|c|c|c|c|c|c|}
\hline Exp. Type & Soil Type & BC Feedstock & Pyrolysis Temperature $\left({ }^{\circ} \mathrm{C}\right)$ & Effect of Biochar Amendment & BC Application Rates & Reference \\
\hline Lab & Ultisols & Crop residue & 400 & $\begin{array}{l}\text { Inhibited soil re-acidification and increased } \mathrm{pH} \\
\text { buffering capacity }\end{array}$ & $3 \%(\mathrm{~W} / \mathrm{W})$ & [105] \\
\hline Lab & Ferrosol & Crop residue & 450 & $\begin{array}{l}\text { Promoted nitrification and inhibited re-acidification of } \\
\text { Cd-contaminated soils }\end{array}$ & $3 \%(\mathrm{~W} / \mathrm{W})$ & [119] \\
\hline Lab & Sandy & Pig manure and poultry litter & 300 & $\begin{array}{c}\text { Decreased soil acidification and increased cation } \\
\text { exchange capacity }\end{array}$ & $0.5 \%, 1 \%$, and $2 \%(\mathrm{~W} / \mathrm{W})$ & [120] \\
\hline \multirow[t]{2}{*}{ Lab } & Ultisols & \multirow{2}{*}{ Crop residue } & \multirow{2}{*}{400} & \multirow{2}{*}{$\begin{array}{l}\text { Increased soil pH buffering capacity and increased the } \\
\text { resistance of soils to re-acidification }\end{array}$} & \multirow{2}{*}{$3 \%$ and $5 \%(\mathrm{~W} / \mathrm{W})$} & \multirow{2}{*}{ [123] } \\
\hline & Oxisol & & & & & \\
\hline Lab & Ultisols & Crop residue & 400 & $\begin{array}{l}\text { Increased soil pH, neutralized soil acidity, increased } \\
\text { soil pH-buffering capacity, and increased resistance of } \\
\text { soils to re-acidification }\end{array}$ & $1 \%$ and $3 \%(\mathrm{~W} / \mathrm{W})$ & [124] \\
\hline Lab & N/A & Crop residue & 500 & $\begin{array}{l}\text { Biochar significantly promoted rice growth and the } \\
\text { yield increased in acidified soil }\end{array}$ & $2 \%(\mathrm{~W} / \mathrm{W})$ & [122] \\
\hline Lab & Oxisols & Crop residue & N/A & Alleviated soil acidification & $1 \%, 2 \%$ and $5 \%(\mathrm{~W} / \mathrm{W})$ & [125] \\
\hline Lab & Loamy sand & Sewage sludge & 300 & Reduced soil acidification & $0.5 \%, 1 \%$ and $2 \%(\mathrm{~W} / \mathrm{W})$ & [126] \\
\hline
\end{tabular}




\section{Biochemical Properties}

\subsection{Soil Organic Matter (SOM)}

Soil organic matter comprises the total organic carbon in a soil and is the main determinant of overall soil fertility. SOM components consist of plant residue, animal waste, microbial populations, and active and stable organic matter in soil. SOM contributes to soil fertility by serving as a nutrient source for crops and microbes, causes soil aggregation, and improves water retention and nutrient exchange. It also helps to reduce soil compaction and surface crusting. It has been reported that the impact of biochar on SOM depends on the following variables [127-129]:

1. Type of biomass used for production of BC

2. Pyrolysis temperature

3. Pre-existing SOM levels in the soil

Amending soils with biochar often results in alterations in C cycling and mineralization, and this effect is known as 'priming'. Previous studies have reported both positive and negative effects of priming. Grass-derived $\mathrm{BC}$ produced at lower temperatures $\left(250^{\circ} \mathrm{C}\right.$ and $\left.400{ }^{\circ} \mathrm{C}\right)$ resulted in positive priming resulting in increased $\mathrm{C}$ mineralization. However, $\mathrm{BC}$ produced at higher temperatures $\left(525^{\circ} \mathrm{C}\right.$ and $600{ }^{\circ} \mathrm{C}$ ) from hardwood resulted in negative priming [128]. It was hypothesized that negative priming resulted from the organic matter binding to the biochar and thereby becoming unavailable to microbial and enzymatic action.

Analogous results were observed in a study that showed that crop residue-derived biochar produced at lower temperature $\left(300-550^{\circ} \mathrm{C}\right)$ generally resulted in positive priming when applied to arable and fallow soils; however, in the case of grassland soils, the effect was negative [127]. In another study, which aimed to analyze the short-term effect of biochar on SOM, BC produced from woody feedstocks at lower temperatures $\left(350^{\circ} \mathrm{C}\right)$ had greater positive priming during $0-13$ days of biochar application both in low and high $\mathrm{pH}$ clay loam soil [130]. The extent of positive priming was reduced for low and high $\mathrm{pH}$ clay loam soil when $\mathrm{BC}$ produced at higher temperature $\left(700^{\circ} \mathrm{C}\right)$ was used. The addition of fresh labile substrate, such as rye grass, to $\mathrm{BC}$ produced at both high and low temperatures further increased priming and mineralization [130]. If the goal is to sequester carbon, rapid mineralization caused in conjunction with low temperature-derived $\mathrm{BC}$ results in carbon loss, necessitating $\mathrm{BC}$ reapplication. The application of high temperature-derived $\mathrm{BC}$ can also be used to reduce the priming effect and aide in carbon sequestration.

The addition of $3 \%(\mathrm{w} / \mathrm{w}) \mathrm{BC}$ prepared from forest residues at $550^{\circ} \mathrm{C}$ has been reported to delay the decomposition of SOM and reduce $\mathrm{N}$ mineralization when added to acidic red loam soil [131]. However, some studies did not find BC to contribute to SOM decomposition [132,133]. A reduction in priming and a $16 \%$ reduction of $\mathrm{SOM}$ decomposition was reported when crop residue-derived $\mathrm{BC}$ pyrolyzed via gasification at $1200{ }^{\circ} \mathrm{C}$ was added to sandy loam soil [134]. The reduction may be due to a shift in the preference of the microbial community for biochar as a $C$ source [135]. There have been various studies in which $\mathrm{BC}$ produced at lower temperature ranging from 450 to $550{ }^{\circ} \mathrm{C}$ stimulated positive priming when added to sandy loam (Table 3). Overall, BC promoted increases in C sequestration, organic carbon retention, SOM, mineralization, phosphorous and potassium content, and plant biomass [136-139]. Conversely, one study reported a decrease in soil microbial biomass and SOM mineralization when crop residue-derived $\mathrm{BC}\left(450^{\circ} \mathrm{C}\right)$ was applied to sandy loam soil [140]. 
Table 3. Selected recent studies summarizing the effect of biochar on soil organic matter (SOM).

\begin{tabular}{|c|c|c|c|c|c|c|}
\hline Exp. Type & Soil Type & BC Feedstock & Pyrolysis Temperature $\left({ }^{\circ} \mathrm{C}\right)$ & Effect of Biochar Amendment & BC Application Rates & Reference \\
\hline Lab & Acidic red loam & Forest residue & 550 & $\begin{array}{l}\text { Decomposition of SOC(soil organic carbon) } \\
\text { declined and reduced mineralization of SOM }\end{array}$ & $1 \%$ and $3 \%(\mathrm{~W} / \mathrm{W})$ & [131] \\
\hline Field & Sandy loam & Crop residue & Gasification at 1200 & Reduced SOM degradation by $16 \%$. & 30 tons ha $^{-1}$ & [134] \\
\hline Lab & Podzol Antric & Woody biomass & 550 & Increased the SOM mineralization & $1 \%(\mathrm{~W} / \mathrm{W})$ & [141] \\
\hline \multirow{2}{*}{ Field } & \multirow{2}{*}{ Sandy } & \multirow{2}{*}{ Crop residue } & 350 & Increased soil organic matter and $\mathrm{N}$ & \multirow{2}{*}{$5 \%(W / W)$} & \multirow{2}{*}[142]{} \\
\hline & & & 450 & Decreased organic matter and $\mathrm{N}$ content & & \\
\hline Field & N/A & Sewage sludge biochar & N/A & SOM are increased & 16.5 tons ha $^{-1}$ & [136] \\
\hline Field & Plaggic Anthrosols & Crop residue & 350 & Positive priming & N/A & [137] \\
\hline Field & Silt loams & Woody biomass & 900 & $\begin{array}{l}\text { Increased soil organic matter, soil } \mathrm{pH}, \\
\text { phosphorus, potassium, sulfur, and the shoot and } \\
\text { root biomass of wheat }\end{array}$ & $12,24.6$, and 49.3 tons ha ${ }^{-1}$ & [138] \\
\hline Field & Sandy loam & Crop residue & 450 to 500 & $\begin{array}{l}\text { Decrease of SOM mineralization, reduce soil } \\
\text { microbial biomass }\end{array}$ & 5.5 tons ha ${ }^{-1}$ & [140] \\
\hline Lab & Sandy loam & Woody biomass & 450 & $\begin{array}{l}\text { Increased organic carbon retention and promoted } \\
\text { carbon sequestration }\end{array}$ & $2 \%, 5 \%$, and $10 \%(\mathrm{~W} / \mathrm{W})$ & [139] \\
\hline Field & Sandy loam & Crop residue & 360 & $\begin{array}{l}\text { SOC increased after biochar application and did } \\
\text { not contribute to soil aggregation }\end{array}$ & 4.5 and 9 tons ha ${ }^{-1}$ year $^{-1}$ & [43] \\
\hline Lab & Sandy loam & Crop residue & 600 & $\begin{array}{l}\text { Significantly increased SOM, microbial } \\
\text { respiration, and microbial biomass }\end{array}$ & $0.5 \%$ and $1 \%(\mathrm{~W} / \mathrm{W})$ & {$[143]$} \\
\hline
\end{tabular}




\subsection{Microbial Activity}

Considerable emphasis has been placed on the topic of microbial dynamics in agricultural systems and their role in crop productivity. The health and diversity of soil microbial populations as a function of agro-ecosystem well-being has diverse implications for water-use efficiency, soil structure and stability, nutrient cycling, disease resistance, and eventual crop productivity $[144,145]$. While other organic amendments are only stable for relatively short periods in the soil environment, BC is more stable and remains in the soil for hundreds to thousands of years, as it is not easily degraded, and it could support soil microbial communities for an extended period of time with reduced inputs [66].

The diverse and specific physiochemical characteristics of BC that influence soil microbial composition are increased labile carbon, $\mathrm{pH}$, surface area for colonization, and water content in amended soils. BC addition induces remodeling of the microbial diversity and community structure of the soil; however, the changes are highly variable and dependent on the individual soil properties [146,147]. It was reported that low pyrolysis temperature $\mathrm{BCs}\left(>350^{\circ} \mathrm{C}\right)$ harbor a greater number of organic residues and are commonly characterized by lower $\mathrm{pH}$. In contrast, at high temperatures $\left(<600^{\circ} \mathrm{C}\right)$, the abundance of organic moieties contributes to the production of a higher $\mathrm{pH} \mathrm{BC}$. It was concluded that pyrolysis temperature (and the BC-related characteristics associated with temperature) is the single most important factor that determines how the microbial communities are influenced [148]. Overall, there is a consensus that BCs foster the growth and maintenance of soil microbial communities [95,149-151].

\subsubsection{Fungi}

In terms of their abundance and diversity, both beneficial [152-154] and detrimental [95,155-157] effects of $\mathrm{BC}$ on fungal communities have been reported. In comparison to bacteria, fungi respond differently to organic and inorganic treatments. Soil bacteria act as better indicators of soil fertility than soil fungi [158]. The mechanisms for improved fungal diversity and abundance appear to be correlated more with the physical microstructure of $\mathrm{BC}$ and the recalcitrant organic carbon than other factors. This was demonstrated in a study where corn straw $\mathrm{BC}\left(500^{\circ} \mathrm{C}\right)$ derived aqueous extractable substances and organic extractable substances, and the remaining solid BC were tested [159]. It has been hypothesized that $\mathrm{BC}$ addition preferably fosters bacterial communities over fungal communities. The bacteria may starve the fungi of $C$ and therefore outcompete them [155].

It was demonstrated that fungal diversity was lowered in soybean and rice straw $\mathrm{BC}\left(500^{\circ} \mathrm{C}\right)$ soils compared to controls, although individual order, family, genus, and species level fungal communities were affected differently [160]. These outcomes could be a result of the "unbalanced competition" theory. This theory describes the phenomena of saprotrophs exponentially increasing their abundance due to the easily mineralizable carbon found in $\mathrm{BC}$, therefore leading to an overall decrease of other fungal groups and potentially suppressing their abundance and diversity [161]. Other speculations underlying decreased fungal diversity and population include the high levels of organic compounds, mineral elements, and higher soil $\mathrm{pH}$ due to $\mathrm{BC}$ amendment [162].

\subsubsection{Bacteria}

The microbial community consisting of bacteria tend to respond positively to $\mathrm{BC}$, as several studies have reported a significant increase in abundance and diversity, after BC application, especially in the rhizosphere soil [162-165]. For example, an increase in specific bacterial families and species such as phosphorous solubilizing [166], nitrifiers [167], and N-fixing and denitrifiers [168] was reported with Malus pumila woodchip BC $\left(500{ }^{\circ} \mathrm{C}\right)$, Eucalyptus saligna hardwood $\mathrm{BC}\left(550{ }^{\circ} \mathrm{C}\right)$, and sugar maple wood $B C\left(400^{\circ} \mathrm{C}\right)$ soil amendment, respectively. Additional studies found only modest or no differences $[140,159,168,169]$. The change in the composition of bacterial communities after the incorporation of $\mathrm{BC}$ in soil is highly dependent on the pre-existing bacterial community, soil type, and overall BC characteristics. 
Generally, the Gram-negative bacterial community is favored in the nutrient-enriched BC-amended soils and initially predominates the soil environment since it performs specific and narrow functions. They outcompete Gram-positive bacteria that rely on recalcitrant $C$ as their main energy source. Gram-positive bacteria become the dominant bacteria type over time due to BC's ability to form stable aggregates with soil organic matter (SOM) [148]. Utilizing sugarcane-derived $\mathrm{BC}\left(450^{\circ} \mathrm{C}\right)$, it was found that bacterial populations increased significantly while fungal populations were significantly reduced in heavy metal-contaminated soils. This was possibly due to the enhanced heavy metal immobilization by the $\mathrm{BC}$ addition, although other factors may have contributed to the observations [162]. Similar results with wood (fir, cedar) BC $\left(450-550{ }^{\circ} \mathrm{C}\right)$ indicated a significant shift toward a bacteria-dominated microbial community in a short-term study ( 3 months) and was attributed to the increased release of labile $\mathrm{C}$ from the $\mathrm{BC}$ or stable SOM-BC aggregates [95]. A study utilizing bamboo $\mathrm{BC}\left(500{ }^{\circ} \mathrm{C}\right)$ provided further support for the concept that bacteria are more sensitive to $\mathrm{BC}$ compared to the fungal community, which was mostly due to increased $\mathrm{pH}$ with increasing $\mathrm{BC}$ addition [170]. These results indicate that alkaline conditions due to $\mathrm{BC}$ amendment (liming effect) favor and promote bacterial growth and may inhibit fungal growth.

The high complexity of BC-soil interactions and microbial community dynamics leaves many 'gray areas' in this field that require further investigation. However, assessing the long-term effects of BC-amended soils and microbial population diversity and activity are highly recommended for future studies. Research has indicated that the BC surface and pores can be inundated with plant exudates and dead cells, inorganic and organic complexes, and larger soil microorganisms. These factors may reduce the total available space for microbial colonization of aged BCs over time [171].

\subsection{Abiotic and Biotic Stressors}

\subsubsection{Heavy Metals}

Soil contamination with organic and inorganic toxins increases environmental and agricultural risks and poses a threat to both plants and humans. Efforts to develop remediation processes that bind the contaminants, limit their mobility and bioavailability, and foster improved soil health are ongoing. Currently, organic materials such as charcoal, soot, kerogen and activated carbon are used as amendments for limiting and reducing the bioavailability of multiple soil contaminants $[172,173]$. The organic contaminants have been shown to sorb preferentially to the carbonaceous fractions present in soil, limiting their bioavailability [174]. BC has also been shown to reduce the bioavailability of heavy metal contaminants. Several studies analyzed the effect of BC amendment on soils contaminated with heavy metals such as arsenic, cadmium $(\mathrm{Cd})$, copper $(\mathrm{Cu})$, nickel $(\mathrm{Ni})$, lead $(\mathrm{Pb})$, and zinc $(\mathrm{Zn})$ [175-177]. The high surface area of BCs results in more effective contaminant binding; however, one of the recent meta-analyses pointed out that the pyrolysis temperature at which a given $\mathrm{BC}$ is produced influences its remediation efficiency and type of contaminant that can be removed [175]. A majority of studies tested the effect of $\mathrm{BC}$ on $\mathrm{Cd}$ pollution and concluded that the higher $\mathrm{BC}$ surface area had a smaller effect on Cd bioavailability [175]. The BCs produced at lower temperatures $\left(300-500{ }^{\circ} \mathrm{C}\right)$ have a higher density of functional groups, while $\mathrm{BC}$ produced at higher temperatures results in a larger surface area and lower density of functional groups. Another study revealed that $\mathrm{BC}$ produced from wheat straw at $450{ }^{\circ} \mathrm{C}$, with a higher density of functional groups, was more effective in treating $\mathrm{Cd}$ and Pd-contaminated soil [178]. However, BC produced at higher temperature is also more alkaline and results in the immobilization of heavy metals in acidic soil via the liming effect. The addition of rice and wheat straw-derived $\mathrm{BC}$ in soils contaminated with $\mathrm{Pb}, \mathrm{Cu}, \mathrm{Cd}$, and $\mathrm{Zn}$ led to a reduced mobility and bioavailability of the heavy metals, resulting in increased yields and a decreased enrichment of heavy metals in the tested plants [176]. Biochar is also used for the remediation of soil from contaminated sites due to rapid industrialization. It has been recently demonstrated that $\mathrm{BC}$ derived from pine wood was able to reduce the bioavailability of $\mathrm{Cd}, \mathrm{Pb}$, and $\mathrm{Zn}$ in metalloid-contaminated soils at a smelting 
site and promoted plant growth [179]. Biochar derived from hardwood $\left(600{ }^{\circ} \mathrm{C}\right)$ was shown to be effective in reducing $\mathrm{Ni}$ and $\mathrm{Zn}$ by $83-93 \%$ in a historically polluted site in the United Kingdom [179].

The effect of sewage sludge $\mathrm{BC}$ pyrolyzed at $330-500{ }^{\circ} \mathrm{C}$ on alleviating heavy metal toxicity was evaluated. It was observed that with the increase in pyrolysis temperature, the availability of heavy metal in tropical soils was decreased [180]. This might be due to the increased $\mathrm{pH}$, pore size, and surface area in the BC produced at higher temperatures leading to the formation of carbonates, sulfates, phosphates, and metal hydroxides [180]. Due to the reduction in the bioavailability of heavy metal cations, maize yields increased in BC-amended soil in comparison to NPK-fertilized soil [180]. Irrigation with untreated wastewater leads to the accumulation of lead, cadmium, zinc, and iron, which can be taken up by plants or leach into ground water, adversely affecting plant growth and human health. In a recent study, the effect of plantain peel-derived biochar $\left(450-500^{\circ} \mathrm{C}\right)$ on potato yield was studied in sandy soil irrigated with wastewater [181]. This BC regime resulted in the adsorption of soil $\mathrm{Cd}$ and $\mathrm{Zn}$ and the reduction of the Cd level by $69 \%$ and 33\% in tuber flesh [181].

A summary of selected studies reporting the effect of BC on the alleviation of heavy metal toxicity is presented in Table 4. Most of the listed studies were carried out in pots. Therefore, large-scale field studies are required to understand the interactions among a particular biochar, soil type, and contaminant. To use biochar for soil remediation, the specific soil and biochar properties must be taken into consideration. Some studies show that certain BC amendment results in high heavy metal immobilization. However, if the mechanism of immobilization is only physical adsorption or cation exchange, these $\mathrm{BCs}$ may not be suitable for long-term remediation due to weakly bound metals. BCs that immobilize heavy metals through precipitation or complex formation should be used for long-term remediation. 
Table 4. Selected recent studies reporting the effect of biochars (BCs) derived from various feedstocks on heavy metal remediation in different types of soils.

\begin{tabular}{|c|c|c|c|c|c|c|}
\hline Exp. Type & Soil Type & BC Feedstock & Pyrolysis Temperature $\left({ }^{\circ} \mathrm{C}\right)$ & Effect of Biochar Amendment & BC Application Rates & Reference \\
\hline $\mathrm{Lab}$ & N/A & $\begin{array}{l}\text { Wood, bamboo, rice straw, } \\
\text { and walnut shell }\end{array}$ & 500 & Reduced $\mathrm{Zn}, \mathrm{Cd}, \mathrm{Cu}$, and $\mathrm{Pb}$ solubility & $5 \%(\mathrm{~W} / \mathrm{W})$ & [182] \\
\hline $\mathrm{Lab}$ & Aridisols & Woodchip-derived biochar & 300 & $\begin{array}{l}\text { Reduced extractable } \mathrm{Cd}, \mathrm{Pd}, \mathrm{Ni} \text {, and } \mathrm{Cu} \text {. Improved } \\
\text { antioxidant enzyme activity. Increased rapeseed fresh } \\
\text { shoot biomass, fresh root biomass, total chlorophyll, } \\
\text { total pigments, carotenoids, and lycopene concentration }\end{array}$ & $1 \%$ and $2 \%(\mathrm{~W} / \mathrm{W})$ & [183] \\
\hline $\mathrm{Lab}$ & Sandy loam soil & Wood derived biochar & $350-500$ & Reduction in the accumulation of $\mathrm{Cu}$ and $\mathrm{Zn}$ in spinach & $5 \%$ and $10 \%(\mathrm{~W} / \mathrm{W})$ & [184] \\
\hline Lab & N/A & Switchgrass and poultry litter & 700 & Decreased the $\mathrm{Zn}, \mathrm{Cd}$, and $\mathrm{Pb}$ bio-accessibility & $0.5 \%, 1.0 \%, 2.0 \%$, and $4.0 \%(\mathrm{~W} / \mathrm{W})$ & [185] \\
\hline Lab & Paddy soil & Wheat straw & 450 & Reduced soil Cd bioavailability & $5 \%$ and $15 \%(\mathrm{~W} / \mathrm{W})$ & [186] \\
\hline $\mathrm{Lab}$ & Clay soil & Corncob biochar & 600 & Reduced lead leaching & $5 \%(W / W)$ & [187] \\
\hline $\mathrm{Lab}$ & N/A & Wheat straw & $350-650$ & $\begin{array}{l}\text { Lower temperature BC led to increased } \mathrm{Zn} \text { (II) and } \mathrm{Cd} \\
\text { (II) immobilization acidic condition, and higher } \\
\text { temperature BC led to increased Zn (II) and Cd (II) } \\
\text { immobilization alkaline condition }\end{array}$ & N/A & [188] \\
\hline \multirow{3}{*}{$\mathrm{Lab}$} & \multirow{3}{*}{ N/A } & Manure & 500 & \multirow{2}{*}{$\begin{array}{l}\text { Promoted } \mathrm{Zn} \text { and Cd precipitation and reduced total } \\
\mathrm{Cd} \text { and Zn concentrations in switchgrass } \\
\text { shoots and roots }\end{array}$} & \multirow{3}{*}{$0 \%, 2.5 \%$, and $5 \%,(\mathrm{~W} / \mathrm{W})$} & \multirow{3}{*}{ [189] } \\
\hline & & Poultry litter & 500 & & & \\
\hline & & Lodgepole pine & $500-700$ & Reduced $\mathrm{Zn}$ concentration in roots & & \\
\hline \multirow{2}{*}{ Lab } & \multirow{2}{*}{ N/A } & Rice husk biochar & \multirow{2}{*}{550} & \multirow{2}{*}{ Decreased leaching of $\mathrm{Cd}, \mathrm{Cu}, \mathrm{Pb}$, and $\mathrm{Zn}$} & \multirow{2}{*}{$0.5 \%, 1 \%$, and $2 \%(\mathrm{~W} / \mathrm{W})$} & \multirow{2}{*}{ [190] } \\
\hline & & Maple leaf biochar & & & & \\
\hline Lab & Stagnic Phaeozem & Pine wood & N/A & $\begin{array}{l}\text { Decreased heavy metal accumulation in above-ground } \\
\text { parts of Hordeum vulgare }\end{array}$ & $2.5 \%(\mathrm{~W} / \mathrm{W})$ & [191] \\
\hline
\end{tabular}




\subsubsection{Salt}

Salt stress is known to negatively affect soil properties, plant development, and crop productivity due to disturbed soil structure, soil organic matter, microbial activity, and C:N ratio. Salt stress causes oxidative stress in plants, down-regulating antioxidant enzyme activity [192]. Due to excessive salinization, the sodium ions bind to cation exchange sites in soil, causing poor crop growth and yields. Although saline soil can be reclaimed by washing or excessively irrigating with water to remove excessive salts, it is neither economically nor physically feasible for large fields [193]. On the other hand, sodic soils require treatment with other cations such as calcium to remove excess sodium from cation exchange sites followed by the leaching of sodium [193]. The application of organic amendments such as manure or compost has been shown to improve soil fertility by reducing salt stress. In saline soil, the organic amendment improves soil porosity, leading to the leaching of excess salt. In sodic soil, organic amendments might help by improving the physical characteristics of soil, such as triggering cation exchange with the calcium present in organic amendment and Na present in soil.

Several studies have reported the positive impact of BC on the nutrient status, conductivity, and improved physical and chemical properties of soil. The variable amount of plant nutrients present in the $\mathrm{BC}$ can compensate for the nutrient deficiency and improve the fertility of saline soils. For example, sodification raises soil $\mathrm{pH}$, thereby limiting the bioavailability of $\mathrm{P}$. In such soils, $\mathrm{BC}$ can act as a P source and improve its availability, aiding plant growth [194].

It has been demonstrated that the mixture of hardwood and softwood biochar produced at $500{ }^{\circ} \mathrm{C}$, when mixed with sandy loam soil and irrigated with a saline solution, improved the yield of potato, maize, and wheat [195-197]. It was also shown that $\mathrm{BC}$ was able to reduce the $\mathrm{Na}^{+} / \mathrm{K}^{+}$ratio in the xylem sap of wheat and potato and reduced Na concentration in maize xylem [197]. When BC produced from wheat straw $\left(350-550{ }^{\circ} \mathrm{C}\right)$ was combined with poultry manure and incorporated into Aqui-Entisol soils, a decrease in Na uptake was observed, leading to increased biomass in maize and an increase of yield in wheat $[194,198]$. Similarly, rice straw-derived BC $\left(600^{\circ} \mathrm{C}\right)$ alleviated salt stress in paddy soil. There was a significant reduction in bulk density, electrical conductivity, exchangeable $\mathrm{Na}$, and exchangeable chlorine ions in the soil, creating favorable conditions for rice seedling growth [199]. A selection of recent reports in which BC addition was reported to alleviate salt stress is summarized in Table 5.

A majority of the reports support the role of $\mathrm{BC}$ in improving soil health, plant growth, and the biological properties of soil. It has been reported that $\mathrm{BC}$ adsorbs Na salt and improves plant growth; however, salt-affected land is only considered reclaimed if the Na salts are removed. Therefore, the repeated application of $\mathrm{BC}$ might have negative consequences in a case where an increased accumulation of Na-salt bound BC aggravates the salinization problem [193]. There is a need for a better understanding of how different BCs interact with different types of salt-affected soils prior to the prescription of any recommendations. 
Table 5. Selected recent studies reporting the effect of biochar on salt stressed soils.

\begin{tabular}{|c|c|c|c|c|c|c|}
\hline Exp. Type & Soil Type & BC Feedstock & Pyrolysis Temp. $\left({ }^{\circ} \mathrm{C}\right)$ & Effect of Biochar Amendment & BC Application Rates & References \\
\hline $\mathrm{Lab}$ & Loam clay & Rice straw & $300-600$ & $\begin{array}{l}\text { Reduced bulk density, electrical } \\
\text { conductivity, exchangeable } \mathrm{Na}^{+} \\
\text {and } \mathrm{Cl}^{-} \text {. Reduced salt } \\
\text { accumulation in rice seedlings. }\end{array}$ & $0.3 \%(\mathrm{~W} / \mathrm{W})$ & [199] \\
\hline Field & N/A & Citrus wood & N/A & $\begin{array}{l}\text { Improved plant growth and } \\
\text { productivity. Improved } \\
\text { nutrient concentration in soil, } \\
\text { dehydration tolerance, } \\
\text { and water retention. }\end{array}$ & 5 and 10 tons $\mathrm{ha}^{-1}$ & [200] \\
\hline $\mathrm{Lab}$ & Coastal soil & Wood chips & 600 & $\begin{array}{l}\text { Improved photosynthetic } \\
\text { performance and alleviated } \\
\text { oxidative damage and } \\
\text { salt stress. }\end{array}$ & $5 \%(\mathrm{~W} / \mathrm{W})$ & [201] \\
\hline $\mathrm{Lab}$ & Sandy clay loam & Rice straw & 450 & $\begin{array}{l}\text { Mitigated oxidative and salt } \\
\text { stress. Reduced Cd and } \mathrm{Na} \\
\text { concentration in plant. }\end{array}$ & $3 \%$ and $5 \%(\mathrm{~W} / \mathrm{W})$ & [202] \\
\hline $\mathrm{Lab}$ & N/A & Maple residues & 560 & $\begin{array}{l}\text { Improved plant growth and } \\
\text { xylem structure. Reduced } \\
\text { salinity and plant } \\
\text { stress hormones. }\end{array}$ & $5 \%$ and $10 \%(\mathrm{~W} / \mathrm{W})$ & [203] \\
\hline $\mathrm{Lab}$ & N/A & Rice straw & 300 & $\begin{array}{l}\text { Increased seed germination } \\
\text { rates of cowpea. Increased } \\
\text { photosynthetic efficiency and } \\
\text { photosynthetic pigments. }\end{array}$ & N/A & [204] \\
\hline
\end{tabular}

\subsubsection{Biotic Stress}

Several recent reports have emerged showing BC to aid plants in countering biotic stresses. It has been suggested that $\mathrm{BC}$-mediated nutrient retention, adsorption, $\mathrm{pH}$ adjustment, and increased water holding provides plants with the capacity to respond to pathogens and to counter the effect of toxic metabolites generated by plants [205].

The severity of gray mold, powdery mildew, and anthracnose on strawberry plants was evaluated in the presence of $3 \%(\mathrm{w} / \mathrm{w})$ citrus-derived $\mathrm{BC}\left(450^{\circ} \mathrm{C}\right)$. It was observed that greenhouse waste-derived biochar when mixed with coconut fiber/peat reduced the severity of gray mold after disease challenge by $74 \%$ in mature strawberry plants and by $53 \%$ in young strawberry plantlets. Post-disease challenge, anthracnose severity was reduced by $39-49 \%$ and powdery mildew severity was reduced by $68 \%$ [206]. Both citrus wood and greenhouse waste-derived BC reduced gray mold severity as well. It was observed that BC application induced the expression of genes related to the systematic acquired resistance and induced systemic pathways, which might have contributed to the reduction in disease severity [206]. The ability of biochar to absorb pathogenic cell wall-degrading enzymes and toxic metabolites produced by soil pathogen Fusarium oxysporum was also tested with tomato seedlings [205]. The tomato seedlings were treated with $3 \% \mathrm{BC}$ produced from eucalyptus wood chips and greenhouse pepper plant waste pyrolyzed at $350^{\circ} \mathrm{C}$ and $600{ }^{\circ} \mathrm{C}$. It was observed that seedlings exposed to enzymes from Fusarium oxysporum and toxic metabolites without BC developed severe disease-like symptoms, whereas those symptoms were significantly reduced in the seedlings grown with BC amendment [205]. The exact mechanism of interaction with $\mathrm{BC}$ is still unclear; however, it was observed that a majority of the fungal enzymes that were immobilized by BC through adsorption were deactivated [205]. A commercial-scale study conducted over a period of 3 years tested the effect of BC on growth and disease resistance in Capsicum annuum L. (sweet pepper) [207]. Pepper seedlings were planted in four combinations of sandy soil amended with biochars produced from greenhouse pepper plant waste and eucalyptus chips. During the first year of growth, it was observed that greenhouse waste-derived BC $\left(450{ }^{\circ} \mathrm{C}\right)$ reduced the severity of powdery mildew by almost $50 \% 168$ days post-planting in comparison with controls. In the second year of the study, the greenhouse waste $\mathrm{BC}\left(350^{\circ} \mathrm{C}\right.$ and $\left.450{ }^{\circ} \mathrm{C}\right)$ showed the highest pepper yield compared to the other treatments and the control [207], in addition to a significant reduction in powdery mildew severity. The incidence of plants affected by broad leaf mite was also reduced when amended with greenhouse waste BC. A comparable trend was observed in the third-year trial. Powdery mildew severity was reduced by $25 \%$ in both greenhouse waste and eucalyptus wood 
chip-derived BC after 160 days of growth [207]. Biochars produced from greenhouse waste $\left(350{ }^{\circ} \mathrm{C}\right)$ and eucalyptus chips $\left(600^{\circ} \mathrm{C}\right)$ were shown to be effective in suppressing crown and root rot in tomato caused by Fusarium oxysporum f. sp. radicis lycopersici [208]. The application of greenhouse waste BC at $0.5 \%, 1 \%$, and $3 \%$ reduced disease severity by $72 \%$. The eucalyptus chip BC also reduced disease severity by $44 \%$ compared to the control plants [208]. There are also some reports where no significant effect of BC on soil-borne pathogen suppression was observed [209-211].

The number of studies exploring the role of $B C$ in pathogen suppression is significantly less than other organic amendments such as compost, peat, and crop residue. Hence, additional studies are needed in order to understand the mechanism behind the ability of biochar to suppress pathogens and to be able to prescribe biochar regimens as safe and effective amendment strategies for the improvement of plant resistance to soil-borne pathogens.

\section{Impact of Biochar on Crop Production}

Increasing crop yields to feed a burgeoning population is a daunting task in the face of a myriad abiotic and biotic challenges, including the reduction of arable farmlands and increased plant stressors due to the changing climate [212-214]. These issues are especially important in organic production systems where the average crop yields are 5-34\% lower compared to conventional farming [215-218]. The use of biochar in soil remediation can be a useful strategy, especially in degraded soils $[219,220]$. Furthermore, the potential to significantly reduce the organic yield gap through better fertilization regimes has been proposed, suggesting an expanded role for nutrient-rich biochars [221].

A meta-analysis of $\mathrm{BC}$ effects on plant productivity concluded that $\mathrm{BC}$ use holds promise as a method to increase crop yields and could further promote ecosystem services and carbon storage [91,222-224]. It was noted that increased soil N, P, K, the reduction of soil acidity due to the liming effect of $\mathrm{BC}$, and improved water relations contributed to various soil and crop responses. In this review, a comprehensive literature search was performed in the Google Scholar search engine with the search terms "biochar crop productivity yield" for the years 2017-2019, which yielded 330 entries. These entries were further parsed using minimal criteria terms-BC feedstock source, pyrolysis temp, retention time, and soil type. The second round reduced the number of entries to 18 . The results of the literature search are summarized in Table 6. 
Table 6. Impact of BC on crop productivity summarized from a comprehensive literature search. Soil types listed in the table correspond to the types reported in the original studies. CEC: cation exchange capacity.

\begin{tabular}{|c|c|c|c|c|c|c|c|}
\hline \multicolumn{4}{|c|}{ Crop Productivity } & \multirow{2}{*}{$\begin{array}{l}\text { Soil type, Experiment } \\
\text { Type, Length }\end{array}$} & \multirow[t]{2}{*}{ Biochar Feedstock } & \multirow{2}{*}{$\begin{array}{c}\text { Pyrolysis Temp }{ }^{\circ} \mathrm{C}, \\
\text { Residence Time, } \\
\text { Application Rate } \\
\end{array}$} & \multirow{2}{*}{ References } \\
\hline Crop Tested & Productivity & Beneficial & Detrimental & & & & \\
\hline \multirow{3}{*}{$\begin{array}{l}\text { Cherry tomato } \\
\text { (Solanum lycopersicum) }\end{array}$} & \multirow{3}{*}{$\begin{array}{l}\text { Bamboo } \mathrm{BC} \text { increased } \\
\text { tomato yields }\end{array}$} & \multirow{3}{*}{$\begin{array}{l}\text { Both BCs improved tomato } \\
\text { quality with increased } \\
\text { total sugars }\end{array}$} & \multirow{3}{*}{$\begin{array}{l}\text { Rice husk BC did not } \\
\text { improve total } \mathrm{N} \%\end{array}$} & Clay loamy & \multirow{3}{*}{ Rice husk and bamboo } & 500 & \multirow{3}{*}{ [225] } \\
\hline & & & & Greenhouse & & $1 \mathrm{~h}$ & \\
\hline & & & & Short-term $\leq 1$ year & & $2 \%$ and $5 \%(w / w)$ & \\
\hline \multirow{3}{*}{ Lettuce (Lactuca sativa) } & \multirow{3}{*}{$\begin{array}{c}\text { For both soils, } \mathrm{BC} \text { rates of } \\
20 \text { and } 30 \mathrm{t} / \mathrm{ha}^{-1} \\
\text { significantly increased } \\
\text { above-ground biomass }\end{array}$} & \multirow{3}{*}{$\begin{array}{l}\text { Effective fertilizer for lettuce } \\
\text { production at least for two } \\
\text { growing cycles }\end{array}$} & \multirow{3}{*}{$\begin{array}{l}\text { Biosolid BC could increase } \\
\text { harmful soil elements such } \\
\text { as heavy metals }\end{array}$} & Silty loam and sandy loam & \multirow{3}{*}{ Fecal matter } & 450 & \multirow{3}{*}{ [226] } \\
\hline & & & & Greenhouse & & $1 \mathrm{~h}$ & \\
\hline & & & & Short-term $\leq 1$ year & & 10,20 , and $30 \mathrm{t} / \mathrm{ha}$ & \\
\hline \multirow{3}{*}{$\begin{array}{l}\text { Chrysanthemum (Glebionis } \\
\text { coronaria, cv. 'Crown Daisy') } \\
\text { Leaf lettuce }\end{array}$} & \multirow{3}{*}{$\begin{array}{l}\text { 3\% BC significantly } \\
\text { decreased yields } \\
\text { No effect }\end{array}$} & \multirow{3}{*}{$\begin{array}{l}\mathrm{BC} \text { increased WHC(water } \\
\text { holding capacity) and SOM }\end{array}$} & \multirow{3}{*}{$\begin{array}{l}\text { Higher BC application } \\
\text { reduced plant productivity }\end{array}$} & Pedocals, silt-clay & \multirow{3}{*}{ Peanut shells } & 350 & \multirow{3}{*}{ [227] } \\
\hline & & & & Greenhouse & & $3 \mathrm{~h}$ & \\
\hline & & & & Short-term $\leq 1$ year & & $\begin{array}{c}0 \%, 1.5 \%, 3 \% \text {, and } 5 \% \\
(\mathrm{w} / \mathrm{w})=\text { to } 0,37.5,75, \text { and } \\
125 \mathrm{t} / \mathrm{ha} \text { in the field }\end{array}$ & \\
\hline \multirow{3}{*}{ Beans } & \multirow{3}{*}{$\begin{array}{c}\text { Bean yields were } \\
\text { significantly reduced with } \\
\text { BC application }\end{array}$} & \multirow{3}{*}{$\begin{array}{l}\text { Increased germination rate in } \\
\text { BC-amended soils }\end{array}$} & \multirow{3}{*}{$\begin{array}{l}\text { Significant decreases in } \\
\text { some macro and } \\
\text { micronutrients }\end{array}$} & Krome loamy & \multirow{3}{*}{$\begin{array}{c}\text { Melaleuca quinquenervia } \\
\text { (Broad-leaved paperbark) } \\
\text { hardwood }\end{array}$} & 350 & \multirow{3}{*}{ [228] } \\
\hline & & & & Greenhouse & & $7 \mathrm{~h}$ & \\
\hline & & & & Short-term $\leq 1$ year & & $2 \%$ and $5 \%(w / w)$ & \\
\hline & & & & Loamy sand & & $300,400,500$, and 600 & \\
\hline Wheat (cv. 'Yecora Rojo') & $\begin{array}{l}300^{\circ} \mathrm{C} \text { BC with NPK } \\
\text { increased vields }\end{array}$ & $\begin{array}{l}\text { Increased soil water retention } \\
\text { and decreased bulk density }\end{array}$ & with BC produced at higher & Greenhouse & Date palm tree residues & $4 \mathrm{~h}$ & [229] \\
\hline & & & temp ${ }^{\circ}\left(400,500,600^{\circ} \mathrm{C}\right)$ & Short-term $\leq 1$ year & & $8 \mathrm{t} / \mathrm{ha}$ & \\
\hline & & & & Sandy & & $450-500$ & \\
\hline $\begin{array}{l}\text { cv. 'Russet Burbank') } \\
\text { cr., }\end{array}$ & 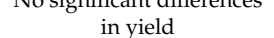 & $B C$ increased soil $C E C$ & greenness rate or & Field Study & Green plantain peels & $18-25 \mathrm{~min}$ & [230] \\
\hline & & & photosystem activity & Long-term, 2 years & & $13.5 \mathrm{t} / \mathrm{ha}(1 \% \mathrm{w} / \mathrm{w})$ & \\
\hline & BC does not have & & Delayed nutrient & Rincon silty clay loam & & 900 & \\
\hline Tomato \& Maize (Zea mays) & a significant long-term & $\begin{array}{l}\text { Increased } \mathrm{K}, \mathrm{Ca}^{-} \text {, and } \\
\text { PO4-P in to soil in year } 2\end{array}$ & availability from $\mathrm{BC}$ and & Field Study & Walnut shells & $1-2 \mathrm{~h}$ & [231] \\
\hline & effect on yield & & short-lived effects & Long-term, 4 years & & $10 \mathrm{t} / \mathrm{ha}$ & \\
\hline & Low levels $(1 \%, 2 \%)$ of $B C$ & & & Silty-clay & & 450 & \\
\hline $\begin{array}{l}\text { Wheat (cv. 'Xiaor } \\
\text { whan no. 22') }\end{array}$ & had a positive effect on & increased with BC & $\mathrm{BC}$ addition decreased the & Outdoor pot study & Apple wood & $8 \mathrm{~h}$ & [232] \\
\hline & yields & & & Short-term $\leq 1$ year & & $1 \%, 2 \%, 4 \%$, and $6 \%(\mathrm{w} / \mathrm{w})$ & \\
\hline & & & & Sandy clay loam & & 500 & \\
\hline Maize & a significant increase in & $\begin{array}{l}\text { De improvea soll } \\
\text { water-holding capacity }\end{array}$ & $\begin{array}{l}\text { DC alone maize yields } \\
\text { mat on }\end{array}$ & Field Study & Maize cobs & $1 \mathrm{~h}$ & [233] \\
\hline & maize yield & & & Short-term $\leq 1$ year & & $20 \mathrm{t} / \mathrm{ha}$ & \\
\hline & & & & Loamy & & 400 & \\
\hline Chinese cabbage (Brassica rapa) & $\begin{array}{l}\text { BC signiticantly improved } \\
\text { crop vields }\end{array}$ & $\mathrm{BC}$ increased soil $\mathrm{pH}$ and $\mathrm{CEC}$ & $\begin{array}{l}\text { BC did not anfect the soll } \\
\text { bulk density and porosity }\end{array}$ & Field Study & Barley straw & $1 \mathrm{~h}$ & [234] \\
\hline & & & & Short-term $\leq 1$ year & & $10 \mathrm{t} / \mathrm{ha}$ & \\
\hline
\end{tabular}


Table 6. Cont.

\begin{tabular}{|c|c|c|c|c|c|c|c|}
\hline & Crop Proc & uctivity & & $\begin{array}{l}\text { Soil type, Experiment } \\
\text { Type, Length }\end{array}$ & Biochar Feedstock & $\begin{array}{l}\text { Pyrolysis Temp }{ }^{\circ} \mathrm{C}, \\
\text { Residence Time, } \\
\text { Application Rate }\end{array}$ & References \\
\hline Crop Tested & Productivity & Beneficial & Detrimental & & & & \\
\hline \multirow{3}{*}{$\begin{array}{l}\text { Radish (Raphanus sativus L. cv. } \\
\text { French Breakfast) }\end{array}$} & \multirow{3}{*}{$\begin{array}{l}\text { Increased yields in } \\
\text { second year }\end{array}$} & \multirow{3}{*}{$\begin{array}{l}\text { Reduced bulk density and } \\
\text { increased porosity, moisture } \\
\text { content, soil pH }\end{array}$} & \multirow{3}{*}{$\begin{array}{l}\text { No effect on } \\
\text { first-year growth }\end{array}$} & Alfisol or Luvisol & \multirow{3}{*}{$\begin{array}{c}\text { Local hardwoods (Parkis biglosa, } \\
\text { Khaya senegalensis, } \\
\text { Prosopis africana and } \\
\text { Terminalia glaucescens) } \\
\end{array}$} & 580 & \multirow{3}{*}{ [53] } \\
\hline & & & & Field Study & & $24 \mathrm{~h}$ & \\
\hline & & & & Long-term, 2 years & & 25 and $50 \mathrm{t} / \mathrm{ha}$ & \\
\hline \multirow{3}{*}{ Rice (cv. 'Naveen') } & \multirow{3}{*}{$\begin{array}{l}\text { Increased grain yield up } \\
\text { to } 24 \%\end{array}$} & \multirow{3}{*}{$\begin{array}{l}\text { Increased total organic } C \\
\text { in soils }\end{array}$} & \multirow{3}{*}{$\begin{array}{l}\text { Microbial carbon use } \\
\text { efficiency decreased due to } \\
\text { BC addition }\end{array}$} & Sandy clay loam & \multirow{3}{*}{ Rice husk } & 350 & \multirow{3}{*}{ [235] } \\
\hline & & & & Field Study & & $6 \mathrm{~h}$ & \\
\hline & & & & Long-term, 3 years & & $0.5,1,2,4,8,10 \mathrm{t} / \mathrm{ha}$ & \\
\hline \multirow{3}{*}{ Maize (cv. 'hybrid LG 6030') } & \multirow{3}{*}{ Increased corn yields } & \multirow{3}{*}{$\begin{array}{l}\text { Increased P levels during the } \\
\text { two years of cultivation }\end{array}$} & \multirow{3}{*}{$\begin{array}{l}\mathrm{BC} \text { was unable to supply } \\
\text { the necessary } \mathrm{K} \text { for further } \\
\text { crop production }\end{array}$} & $\begin{array}{l}\text { Red-Yellow Latosol with } \\
\text { clayey texture }\end{array}$ & \multirow{3}{*}{ Sewage sludge } & 300 and 500 & \multirow{3}{*}{ [236] } \\
\hline & & & & Field Study & & $30 \mathrm{~min}$ & \\
\hline & & & & Long-term, 2 years & & $15 \mathrm{Mg} / \mathrm{ha}$ & \\
\hline \multirow{3}{*}{$\begin{array}{l}\text { Okra (Abelmoschus esculentus L., } \\
\text { cv. 'OH-397') }\end{array}$} & \multirow{3}{*}{$\begin{array}{l}\text { Increased yields } \\
\text { vs. controls }\end{array}$} & \multirow{3}{*}{$\begin{array}{l}\text { Significant increase in SOC } \\
\text { and microbial activity }\end{array}$} & \multirow{3}{*}{$\begin{array}{l}\text { Lower benefit cost ratios for } \\
\text { BC compared to controls }\end{array}$} & $\begin{array}{l}\text { Inceptisol with sandy } \\
\text { loam texture }\end{array}$ & \multirow{3}{*}{ Mixed local hardwoods } & 450 & \multirow{3}{*}{ [237] } \\
\hline & & & & Field Study & & $4 \mathrm{~h}$ & \\
\hline & & & & Long-term, 2 years & & $5 \mathrm{t} / \mathrm{ha}$ & \\
\hline \multirow{3}{*}{$\begin{array}{l}\text { Rice (Oryza sativa L.) \& Wheat } \\
\text { (Triticum ssp.) }\end{array}$} & \multirow{3}{*}{ Not affected } & \multirow{3}{*}{$\begin{array}{l}\text { BC amendment increased the } \\
\text { soil water-holding capacity, } \\
\text { soil nutrients, and SOC }\end{array}$} & \multirow{3}{*}{$\begin{array}{l}\text { Short-term effects and BC } \\
\text { alone did not increase yields }\end{array}$} & $\begin{array}{l}\text { Hydragric Anthrosol, } \\
\text { sandy }\end{array}$ & \multirow{3}{*}{ Wheat straw } & $350-550$ & \multirow{3}{*}{ [166] } \\
\hline & & & & Field Study & & $2-3 \mathrm{~h}$ & \\
\hline & & & & Long-term, 6 years & & 20 and $40 \mathrm{t} / \mathrm{ha}$ & \\
\hline \multirow{3}{*}{$\begin{array}{l}\text { Sunflower (Helianthus annuus L., } \\
\text { cv. 'Embrapa } 122 / \mathrm{V} 2000^{\prime} \text { ) }\end{array}$} & Sunflower seed and oil & Increased levels of most soil & $\begin{array}{l}\text { Nitrogen levels in leaves } \\
\text { and the nitrogen uptake of }\end{array}$ & $\begin{array}{l}\text { Dark red soil, Typic } \\
\text { Hapludalfs }\end{array}$ & Sugarcane bagasse and sunflower & $500-600$ & \\
\hline & yield declined & $\begin{array}{l}\text { minerals and total } \\
\text { carbon levels }\end{array}$ & the entire plant decreased & Field Study & & $1 \mathrm{~h}$ & [238] \\
\hline & & & & Short-term $\leq 1$ year & & $1 \%(\mathrm{w} / \mathrm{w})$ & \\
\hline Spring barley (Hordeum vulgare L.) & $\begin{array}{l}\text { Increased yields with } \\
\text { BC + NPK }\end{array}$ & $\begin{array}{l}\text { Increased soil water status in } \\
\mathrm{BC} \text { amended soils in the first }\end{array}$ & $\begin{array}{l}\text { BC only decreased yields } \\
\text { for both crops compared to }\end{array}$ & $\begin{array}{c}\text { Sandy loamy silt; } \\
\text { calcareous Chernozem on } \\
\text { loess } \\
\end{array}$ & Hardwood & 550 & [239] \\
\hline & & year; increased soil & control NPK plants & Field Study & & $2 \mathrm{~h}$ & \\
\hline Sunflower & No difference vs. controls & carbon status & & Long-term, 2 years & & $72 \mathrm{t} / \mathrm{ha}$ & \\
\hline Rice (Oryza sativa L.) \& Wheat & & $\mathrm{BC}$ amendment increased the & Short-term effects and BC & $\begin{array}{l}\text { Hydragric Anthrosol, } \\
\text { sandy }\end{array}$ & & $350-550$ & \\
\hline (Triticum ssp.) & Not affected & $\begin{array}{l}\text { soil water-holding capacity, } \\
\text { soil nutrients, and SOC }\end{array}$ & alone did not increase yields & Field Study & Wheat straw & $2-3 \mathrm{~h}$ & [166] \\
\hline & & & & Long-term, 6 years & & 20 and $40 \mathrm{t} / \mathrm{ha}$ & \\
\hline $\begin{array}{c}\text { Cauliflower (Brassica oleracea, } \\
\text { cv. 'Desire') }\end{array}$ & No significant & No negative effects to crop & Soil moisture and bulk & Ferralsol & 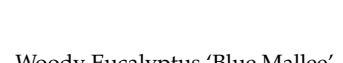 & 550 & \\
\hline Pea (Pisum sativum, cv. 'Ashton') & improvement in & productivity or soil quality & $\begin{array}{l}\text { density not affected by } \\
B C \text { additions }\end{array}$ & Field Study & Woody Eucaly prus biue Manlee & $30 \mathrm{~min}$ & [240] \\
\hline Broccoli 'Ironman' & & & & Short-term, 1 year & & $10 \mathrm{t} / \mathrm{ha}$ & \\
\hline
\end{tabular}


In terms of productivity alone, a majority of the studies reported a beneficial impact of BC on crop yields [53,225,226,229,232-237]. Experimental plants included lettuce, cabbage, radish, tomato, wheat, rice, maize, and okra. Soils were amended with BC derived from major feedstock sources such as hardwood, manure, and crop residues. Positive results from this mixture of plants and biochars indicate a theoretical system to 'mix and match' crop with BC for optimal productivity. Interestingly, none of the studies included perennial plant species in the experimental design. That is another area where the impact of $\mathrm{BC}$ remains to be assessed.

Due to the range of tested soil conditions, many factors altered by BC amendment were implicated in reported yield gains. For instance, lettuce yields were positively influenced with 20 and $30 \mathrm{t} / \mathrm{ha}$ fecal-derived BC $\left(450{ }^{\circ} \mathrm{C}\right)$ [226]. Mineral-enriched BC proved to be an effective fertilizer for two growing cycles in the greenhouse pot study. Additional experiments in greenhouses with leafy crops proved that significant yield increases are possible with BC soil amendment $[20,241]$. Two studies with wheat showed increased yields as a result of soils amended with $1-2 \%$ apple wood-derived $B C\left(450{ }^{\circ} \mathrm{C}\right)$ due to increased nitrogen levels [232] and increased soil water retention with $8 \mathrm{t} /$ ha date palm tree residue-derived $\mathrm{BC}\left(300-600^{\circ} \mathrm{C}\right)$ [229]. The increase in soil organic carbon and the stimulatory effect on microbial communities raised rice yields in soil amended with rice husk $\mathrm{BC}\left(350^{\circ} \mathrm{C}\right)$ [235] and okra yields amended with hardwood-derived $\mathrm{BC}\left(450^{\circ} \mathrm{C}\right)$ [237]. In addition to reporting increases in yields, these studies also discussed the limitations of field applications of BC.

$\mathrm{BC}$ contains key plant nutrients, although at a low level as demonstrated by several studies, and it may have led to the lack of a complete plant nutrient profile in the soils to obtain a desirable increase in yields [225]. Multiple studies reported mixed results in terms of crop production [227,239] or described no effect $[166,230,231,240]$. Soil nutrient content and CEC were improved with BC amendment but were short-lived and resulted in comparable crop productivity compared to controls in studies with rice and wheat growing in wheat straw $\mathrm{BC}\left(350-550^{\circ} \mathrm{C}\right)$ [166], potatoes with green plantain peel-derived $\mathrm{BC}$ $\left(450-500{ }^{\circ} \mathrm{C}\right)$ [230], and tomatoes and maize with walnut shell-derived $\mathrm{BC}\left(900^{\circ} \mathrm{C}\right)$ [231]. The growth of Spring barley and sunflowers was tested with hardwood-derived $B C\left(550^{\circ} \mathrm{C}\right)$ at $72 \mathrm{t} / \mathrm{ha}$. The treatments increased barley yields but had no effect on sunflower productivity [239]. The BC-only amendment did increase soil water status and carbon levels; however, increased barley productivity was noted only when BC was mixed with NPK compared to NPK-only controls. While increased water-holding capacity and soil carbon levels with peanut shell-derived BC $\left(350{ }^{\circ} \mathrm{C}\right)$ were also reported [227], these alterations did not lead to any effect on lettuce yields.

Undesirable effects on crop productivity following BC soil amendment were also reported in two of the studies $[228,238]$. Although beans demonstrated an increased rate of germination in BC amended soils, their yields were significantly reduced with hardwood $\mathrm{BC}\left(350^{\circ} \mathrm{C}\right)$ application at $2 \%$ and 5\% [228]. Other studies with legumes reported a gain in yield when grown in BC-amended soils. The yields of mash bean improved with sugarcane bagasse $\mathrm{BC}\left(350^{\circ} \mathrm{C}\right)$, with and without chemical fertilizer, due to the increased SOC, total N, and decreased bulk density. Importantly, nitrogen fixation increased by $83 \%$ in the biochar-only treatment due to higher nodule numbers [242]. Additionally, fava bean growth with wheat straw-derived $\mathrm{BC}\left(500^{\circ} \mathrm{C}\right)$ amendment applied at a $2.5 \% \mathrm{w} / \mathrm{w}$ rate in addition to saltwater irrigation led to significantly increased dry seed yield compared to controls, which was mainly attributed to the high salt sorption capacity of BC [243]. The higher nutrient content in the crop residue-derived $\mathrm{BC}$ s reported above may have helped elevate yields compared to controls, while the already nutrient poor hardwood-derived BC may have reduced bean yields. While BC can be a source of nutrients, the complex interactions in the soil environment may have reduced the capacity of available nutrients in the soils inflicting significant yield losses [244]. Additional studies are required to develop a more comprehensive model of BC effect on legume production.

Other factors potentially responsible for lower productivity include soil nutrient deficiencies found with sugarcane bagasse and sunflower-derived BC-amended $\left(500-600{ }^{\circ} \mathrm{C}\right)$ soils [238]. As a result of decreased nitrogen uptake with increasing $B C$ application, sunflower seed and oil yield saw a significant decrease. The $1 \%$ field application of the BCs may have increased specific communities of bacteria and 
enhanced certain enzyme activity such as urease, which is an important enzyme in soil nitrogen status, as reported by a field study with the addition of sugarcane bagasse biochar (SCBC) [162]. However, fungal communities suffered due to SCBC addition, and final yields of Brassica chinesis L. (pak choi) were reduced compared to controls. It was found that a $4 \%$ application rate of SCBC supported normal plant growth and increased sugar and cane yields [245]. The SOC, soil-water related properties, and nutrient levels were enhanced by SCBC, leading to increased plant productivity. Further research is needed to identify BCs appropriate for specific plant species and initial soil characteristics for improved plant growth and development.

Although crop responses were generally positive, the high variability within the listed studies makes it difficult to draw any broad conclusions except that the type and application rate of $\mathrm{BC}$ will require customization. The benefits of $\mathrm{BC}$ application mainly consist of increased water-holding potential, better nutrient cycling, and increased soil carbon reserves. This may lead to no effect or only minimally increasing yields in the short term, but further testing in the field should illuminate the effects of long-term BC amendment on crop yields [246]. Other regions of industrial agriculture and tropical environments may show a more pronounced $\mathrm{BC}$ effect and may be better at exploiting the advantages of $\mathrm{BC}$. $\mathrm{BC}$ application in marginal soils will likely lead to increased crop productivity by increasing the overall soil fertility through $\mathrm{pH}$ and CEC adjustments, better water retention, and increased microbial activity $[247,248]$. Nevertheless, considerable caution should be observed when using extremely heavy rates of BC. The elevated risk of heavy metal contamination due to feedstocks rich in accumulated metals or other phytotoxic compounds could decrease crop productivity with increasing BC applications [249,250].

The overall conclusion is that $\mathrm{BC}$ application is favorable for improving crop productivity sustainably. Certain agricultural systems require different inputs to achieve higher crop yields, and designing BC to meet those specific needs could lead to optimized production methods and products.

\section{Conclusions and Future Opportunities}

Analysis of the published literature supports the role of $\mathrm{BC}$ as one of the many viable solutions to soil-related challenges of food production in the face of persistent global issues. While it is not a panacea, the humble porous carbon-composed BC has the ability to physically, biologically, and chemically alter soil properties, which has multifarious consequences. There is an opportunity for carbon sequestration and establishing carbon negative cycles with the expanded use of BC. Countering deteriorating soil health due to industrial agriculture, $\mathrm{BC}$ amendment can help support higher crop productivity and contribute to improving global food security. The overall impact of $\mathrm{BC}$ can be increased by its application on highly weathered and marginal soils that are characterized by depleted nutrients levels, reduced water retention, and the lack of a competent soil structure.

Future climate models indicate that water stress will be a key driver of reduced crop productivity. $\mathrm{BC}$ has been shown to improve soil water-holding capacity, making it a potential candidate for alleviating water stress [251-253]. Finding the right permutation of BC feedstock, application rate, and crop variety are vital for improving agricultural production and reducing the related carbon footprint. Initial progress in understanding the effects of BC use has led to the efforts of producing 'designer biochars' which promise to exploit the positive properties and dampen negative effects mainly through feedstock selection but also through chemical, physical, or natural alterations of the BC [91,254-256].

Various studies and published meta-analyses on BC have pointed out the benefits of BC soil amendment; however, there are still several areas that require attention and resolution. Important aspects that affect crop productivity include feedstock sources, various BC production methods, initial soil characteristics, crop variety, and experimental conditions. Others have also reported irregular effects of BC on crop productivity due to these variables [257]. Since it is an irreversible 
decision to amend soils with $B C$, the various impacts of augmenting soils are important considerations before conducting field applications [258].

Several articles were not included in the comprehensive literature review due to the omission of key variables that are critical for assessing the overall impact of BC studies. The conclusions of this review are that standardizing $\mathrm{BC}$ experiments is vitally important to hypothesis testing and replicating studies to move the research field forward. All future BC articles should include meticulous descriptions of biochar feedstock sources, pyrolysis temperature, and retention time. Not covered in this review, but still significant, are the various economic factors to be considered before undertaking any large-scale $\mathrm{BC}$ applications, including the production or acquisition of BC, shipping and transporting, and the time and labor required for field application $[237,259]$. Additionally, the lack of consistent responses of microbial communities to $\mathrm{BC}$ amendment highlights a knowledge gap regarding the mechanism by which microbes interact with BC. BC has the potential to decrease the bioavailability and efficiency of some herbicides, which is yet another variable that needs consideration [260]. Further, analysis of the published literature leads to the conclusion that the following areas need further investigation:

- Biomes underrepresented in the current biochar-associated literature, such as forests and perennial crops (the vast majority of BC studies are directed toward temperate and tropical areas);

- Effects of biochar on non-model crop species (present studies primarily focus on model organisms such as tomato, maize, rice, and wheat);

- Evaluation of BC in field studies to build upon the extensive greenhouse studies;

- Develop an understanding of the highly complex interactions between different soil types, different biochar types, and their impact on plant productivity

- Assessment of biochar-amended soil microbial activity through meta-genomics approaches;

- Longer-term experiments to understand characteristics of 'aged' BC to assess its temporally evolving properties in soils;

- Development of cost-effective ways to minimize environmental impacts by incorporating organic fertilizer amendments such as BC.

The multidimensional and complex interactions between inherent soil properties, variable biochar properties depending on the type of feedstock used, the genetic background of the plant, and the limited amount of available empirical data make it almost impossible to predict the outcome of BC amendment. This is an obvious conclusion of this and several previous studies. Knowledge generated from the above-mentioned areas of investigation is expected to enable the large-scale utilization of biochars in agriculture, representing a step toward establishing carbon negative ecosystems.

Author Contributions: Conceptualization-A.D., E.T. and R.G.; Resources-A.D.; Writing-review and editing-E.T., R.G., A.D.; Supervision-A.D.; Funding acquisition-A.D. All authors have read and agreed to the published version of the manuscript.

Funding: This work was supported in part by the USDA-NIFA Hatch Grant WNP00011 to A.D.

Acknowledgments: The authors thank Seanna Hewitt, Karen Adams, and Richard Sharpe for their critical reading of the manuscript and their feedback.

Conflicts of Interest: A.D. serves as a consultant for AgEnergy Solutions-A biochar production startup company based in Spokane, WA, USA. AgEnergy Solutions had no role in the design of the study; in the collection, analyses, or interpretation of data; in the writing of the manuscript, or in the decision to publish the results. 


\section{Abbreviations}

$\begin{array}{ll}\text { BC } & \text { biochar } \\ \text { SOM } & \text { soil organic matter } \\ \text { GHG } & \text { greenhouse gas } \\ \text { CEC } & \text { cation exchange capacity } \\ \text { FTIR } & \text { Fourier transform infrared spectroscopy } \\ \text { SBBC } & \text { sugarcane bagasse biochar } \\ \mathrm{C} & \text { carbon } \\ \mathrm{N} & \text { nitrogen } \\ \mathrm{P} & \text { phosphorous } \\ \mathrm{K} & \text { potassium } \\ \mathrm{Ca} & \text { calcium } \\ \mathrm{Mg} & \text { magnesium } \\ \mathrm{Fe} & \text { iron } \\ \mathrm{Na} & \text { sodium } \\ \mathrm{Si} & \text { silicon } \\ \mathrm{Cd} & \text { cadmium } \\ \mathrm{Cu} & \text { copper } \\ \mathrm{Ni} & \text { nickel } \\ \mathrm{Pb} & \text { lead } \\ \mathrm{Zn} & \text { zinc }\end{array}$

\section{References}

1. Foley, J.A.; Ramankutty, N.; Brauman, K.A.; Cassidy, E.S.; Gerber, J.S.; Johnston, M.; Mueller, N.D.; O'Connell, C.; Ray, D.K.; West, P.C.; et al. Solutions for a cultivated planet. Nature 2011, 478, 337-342. [CrossRef]

2. Raupach, M.R.; Marland, G.; Ciais, P.; Le Quéré, C.; Canadell, J.G.; Klepper, G.; Field, C.B. Global and regional drivers of accelerating $\mathrm{CO}_{2}$ emissions. Proc. Natl. Acad. Sci. USA 2007, 104, 10288-10293. [CrossRef] [PubMed]

3. The Paris Agreement|UNFCCC. Available online: https://unfccc.int/process-and-meetings/the-parisagreement/the-paris-agreement (accessed on 21 March 2020).

4. Minasny, B.; Malone, B.P.; McBratney, A.B.; Angers, D.A.; Arrouays, D.; Chambers, A.; Chaplot, V.; Chen, Z.-S.; Cheng, K.; Das, B.S. Soil carbon 4 per mille. Geoderma 2017, 292, 59-86. [CrossRef]

5. Meinshausen, M.; Meinshausen, N.; Hare, W.; Raper, S.C.B.; Frieler, K.; Knutti, R.; Frame, D.J.; Allen, M.R. Greenhouse-gas emission targets for limiting global warming to 2 C. Nature 2009, 458, 1158-1162. [CrossRef]

6. Smith, P. Soil carbon sequestration and biochar as negative emission technologies. Glob. Chang. Biol. 2016, 22, 1315-1324. [CrossRef]

7. Canadell, J.G.; Raupach, M.R. Managing forests for climate change mitigation. Science 2008, 320, $1456-1457$. [CrossRef]

8. Creutzig, F.; Ravindranath, N.H.; Berndes, G.; Bolwig, S.; Bright, R.; Cherubini, F.; Chum, H.; Corbera, E.; Delucchi, M.; Faaij, A. Bioenergy and climate change mitigation: An assessment. GCB Bioenergy 2015, 7, 916-944. [CrossRef]

9. Socolow, R.; Desmond, M.; Aines, R.; Blackstock, J.; Bolland, O.; Kaarsberg, T.; Lewis, N.; Mazzotti, M.; Pfeffer, A.; Sawyer, K. Direct Air Capture of $\mathrm{CO}_{2}$ with Chemicals: A Technology Assessment for the APS Panel on Public Affairs; American Physical Society, 2011. Available online: https:/www.aps.org/policy/reports/ assessments/upload/dac2011.pdf (accessed on 21 March 2020).

10. Atafar, Z.; Mesdaghinia, A.; Nouri, J.; Homaee, M.; Yunesian, M.; Ahmadimoghaddam, M.; Mahvi, A.H. Effect of fertilizer application on soil heavy metal concentration. Environ. Monit. Assess. 2010, 160, 83. [CrossRef] [PubMed]

11. Wang, J.; Yu, L.; Hu, L.; Chen, G.; Xin, H.; Feng, X. Ambient ammonia synthesis via palladium-catalyzed electrohydrogenation of dinitrogen at low overpotential. Nat. Commun. 2018, 9, 1-7. [CrossRef] [PubMed] 
12. Clarke, B.O.; Smith, S.R. Review of "emerging" organic contaminants in biosolids and assessment of international research priorities for the agricultural use of biosolids. Environ. Int. 2011, 37, 226-247. [CrossRef]

13. Hamilton, K.A.; Ahmed, W.; Rauh, E.; Rock, C.; McLain, J.; Muenich, R.L. Comparing microbial risks from multiple sustainable waste streams applied for agricultural use: Biosolids, manure, and diverted urine. Curr. Opin. Environ. Sci. Health 2020, 14, 37-50. [CrossRef]

14. Smith, N.J.H. The Amazon River Forest: A Natural History of Plants, Animals, and People. In OUP Catalogue; Oxford University Press: Oxford, UK, 1999.

15. Skjemstad, J.O.; Reicosky, D.C.; Wilts, A.R.; McGowan, J.A. Charcoal carbon in US agricultural soils. Soil Sci. Soc. Am. J. 2002, 66, 1249-1255. [CrossRef]

16. Glaser, B.; Haumaier, L.; Guggenberger, G.; Zech, W. The 'Terra Preta' phenomenon: A model for sustainable agriculture in the humid tropics. Naturwissenschaften 2001, 88, 37-41. [CrossRef]

17. Zech, W.; Haumaier, L.; Reinhold, H. Ecological aspects of soil organic matter in tropical land use. Humic Subst. Soil Crop Sci. Sel. Read. 1990, 187-202. [CrossRef]

18. Smith, N.J.H. Anthrosols and human carrying capacity in Amazonia. Ann. Assoc. Am. Geogr. 1980, 70, 553-566. [CrossRef]

19. Woolf, D.; Amonette, J.E.; Street-Perrott, F.A.; Lehmann, J.; Joseph, S. Sustainable biochar to mitigate global climate change. Nat. Commun. 2010, 1, 56. [CrossRef]

20. Trupiano, D.; Cocozza, C.; Baronti, S.; Amendola, C.; Vaccari, F.P.; Lustrato, G.; Di Lonardo, S.; Fantasma, F.; Tognetti, R.; Scippa, G.S. The Effects of Biochar and Its Combination with Compost on Lettuce (Lactuca sativa L.) Growth, Soil Properties, and Soil Microbial Activity and Abundance. Int. J. Agron. 2017, 2017, 3158207. [CrossRef]

21. Ahmed, M.B.; Zhou, J.L.; Ngo, H.H.; Guo, W. Insight into biochar properties and its cost analysis. Biomass Bioenergy 2016, 84, 76-86. [CrossRef]

22. Al Arni, S. Comparison of slow and fast pyrolysis for converting biomass into fuel. Renew. Energy 2018, 124, 197-201. [CrossRef]

23. Suliman, W.; Harsh, J.B.; Abu-Lail, N.I.; Fortuna, A.-M.; Dallmeyer, I.; Garcia-Perez, M. Influence of feedstock source and pyrolysis temperature on biochar bulk and surface properties. Biomass Bioenergy 2016, 84, 37-48. [CrossRef]

24. Fu, P.; Hu, S.; Xinag, J.; Sun, L.; Yang, T.; Zhang, A.; Wang, Y.; Chen, G. Effects of Pyrolysis Temperature on Characteristics of Porosity in Biomass Chars. In Proceedings of the 2009 International Conference on Energy and Environment Technology(IEEE), Guilin, China, 16-18 October 2009; Volume 1, pp. 109-112.

25. Lehmann, J.; Joseph, S. Biochar for Environmental Management: Science, Technology and Implementation; Routledge: Abingdon, UK, 2015; ISBN 1134489536.

26. Dai, Z.; Zhang, X.; Tang, C.; Muhammad, N.; Wu, J.; Brookes, P.C.; Xu, J. Potential role of biochars in decreasing soil acidification-A critical review. Sci. Total Environ. 2017, 581, 601-611. [CrossRef] [PubMed]

27. Yuan, J.-H.; Xu, R.-K.; Zhang, H. The forms of alkalis in the biochar produced from crop residues at different temperatures. Bioresour. Technol. 2011, 102, 3488-3497. [CrossRef] [PubMed]

28. Dai, Z.; Brookes, P.C.; He, Y.; Xu, J. Increased agronomic and environmental value provided by biochars with varied physiochemical properties derived from swine manure blended with rice straw. J. Agric. Food Chem. 2014, 62, 10623-10631. [CrossRef] [PubMed]

29. Zhao, L.; Cao, X.; Mašek, O.; Zimmerman, A. Heterogeneity of biochar properties as a function of feedstock sources and production temperatures. J. Hazard. Mater. 2013, 256, 1-9. [CrossRef]

30. Flowers, M.D.; Lal, R. Axle load and tillage effects on soil physical properties and soybean grain yield on a mollic ochraqualf in northwest Ohio. Soil Tillage Res. 1998, 48, 21-35. [CrossRef]

31. Bruand, A.; Gilkes, R.J. Subsoil bulk density and organic carbon stock in relation to land use for a Western Australian Sodosol. Soil Res. 2002, 40, 999-1010. [CrossRef]

32. Beutler, A.N.; Centurion, J.F.; da Silva, A.P.; da Centurion, M.A.P.C.; Leonel, C.L.; da Freddi, O.S. Soil compaction by machine traffic and least limiting water range related to soybean yield. Pesqui. Agropecu. Bras. 2008, 43, 1591-1600. [CrossRef]

33. Ramazan, M.; Khan, G.D.; Hanif, M.; Ali, S. Impact of soil compaction on root length and yield of corn (Zea mays) under irrigated condition. Middle-East J. Sci. Res. 2012, 11, 382-385. 
34. Omondi, M.O.; Xia, X.; Nahayo, A.; Liu, X.; Korai, P.K.; Pan, G. Quantification of biochar effects on soil hydrological properties using meta-analysis of literature data. Geoderma 2016, 274, 28-34. [CrossRef]

35. Blanco-Canqui, H. Biochar and soil physical properties. Soil Sci. Soc. Am. J. 2017, 81, 687-711. [CrossRef]

36. Obour, P.B.; Danso, E.O.; Yakubu, A.; Abenney-Mickson, S.; Sabi, E.B.; Darrah, Y.K.; Arthur, E. Water Retention, Air Exchange and Pore Structure Characteristics after Three Years of Rice Straw Biochar Application to an Acrisol. Soil Sci. Soc. Am. J. 2019, 83, 1664-1671. [CrossRef]

37. de Jesus Duarte, S.; Glaser, B.; Pellegrino Cerri, C. Effect of Biochar Particle Size on Physical, Hydrological and Chemical Properties of Loamy and Sandy Tropical Soils. Agronomy 2019, 9, 165. [CrossRef]

38. Verheijen, F.G.A.; Zhuravel, A.; Silva, F.C.; Amaro, A.; Ben-Hur, M.; Keizer, J.J. The influence of biochar particle size and concentration on bulk density and maximum water holding capacity of sandy vs sandy loam soil in a column experiment. Geoderma 2019, 347, 194-202. [CrossRef]

39. Rahim, H.U.; Mian, I.A.; Arif, M.; Rahim, Z.U.; Ahmad, S.; Khan, Z.; Zada, L.; Khan, M.A.; Haris, M. 3. Residual effect of biochar and summer legumes on soil physical properties and wheat growth. Pure Appl. Biol. 2019, 8, 16-26. [CrossRef]

40. You, J.; Sun, L.; Liu, X.; Hu, X.; Xu, Q. Effects of sewage sludge biochar on soil characteristics and crop yield in Loamy sand soil. Pol. J. Environ. Stud. 2019, 28. [CrossRef]

41. Duarte, S.D.J.; Glaser, B.; De Lima, R.P.; Cerri, C.P. Chemical, Physical, and Hydraulic Properties as Affected by One Year of Miscanthus Biochar Interaction with Sandy and Loamy Tropical Soils. Soil Syst. 2019, 3, 24. [CrossRef]

42. Nikravesh, I.; Boroomandnasab, S.; Abd Ali Naseri, A.S.M. Wheat Straw Biochar Application to Loam-Sand Soil: Impact on Yield Components of Summer Maize and Some Soil Properties. World 2019, 8, 54-60.

43. Zhou, H.; Fang, H.; Zhang, Q.; Wang, Q.; Chen, C.; Mooney, S.J.; Peng, X.; Du, Z. Biochar enhances soil hydraulic function but not soil aggregation in a sandy loam. Eur. J. Soil Sci. 2019, 70, 291-300. [CrossRef]

44. Zhang, L.; Jing, Y.; Chen, G.; Wang, X.; Zhang, R. Improvement of physical and hydraulic properties of desert soil with amendment of different biochars. J. Soils Sediments 2019, 19, 2984-2996. [CrossRef]

45. Kätterer, T.; Roobroeck, D.; Andrén, O.; Kimutai, G.; Karltun, E.; Kirchmann, H.; Nyberg, G.; Vanlauwe, B.; de Nowina, K.R. Biochar addition persistently increased soil fertility and yields in maize-soybean rotations over 10 years in sub-humid regions of Kenya. Field Crop. Res. 2019, 235, 18-26. [CrossRef]

46. Badawi, M.A. Production of Biochar from Date Palm Fronds and its Effects on Soil Properties. By-Prod. Palm Trees Appl. 2019, 11, 159.

47. Tanure, M.M.C.; da Costa, L.M.; Huiz, H.A.; Fernandes, R.B.A.; Cecon, P.R.; Pereira Junior, J.D.; da Luz, J.M.R. Soil water retention, physiological characteristics, and growth of maize plants in response to biochar application to soil. Soil Tillage Res. 2019, 192, 164-173. [CrossRef]

48. Lentz, R.D.; Ippolito, J.A.; Lehrsch, G.A. Biochar, manure, and sawdust alter long-term water retention dynamics in degraded soil. Soil Sci. Soc. Am. J. 2019, 83, 1491-1501. [CrossRef]

49. Huang, M.; Zhang, Z.; Zhai, Y.; Lu, P.; Zhu, C. Effect of straw biochar on soil properties and wheat production under saline water irrigation. Agronomy 2019, 9, 457. [CrossRef]

50. Xiu, L.; Zhang, W.; Sun, Y.; Wu, D.; Meng, J.; Chen, W. Effects of biochar and straw returning on the key cultivation limitations of Albic soil and soybean growth over 2 years. Catena 2019, 173, 481-493. [CrossRef]

51. Horák, J.; Šimanský, V.; Igaz, D. Biochar and biochar with N fertilizer impact on soil physical properties in a silty loam haplic luvisol. J. Ecol. Eng. 2019, 20,31-38. [CrossRef]

52. Baiamonte, G.; Crescimanno, G.; Parrino, F.; De Pasquale, C. Effect of biochar on the physical and structural properties of a sandy soil. Catena 2019, 175, 294-303. [CrossRef]

53. Adekiya, A.O.; Agbede, T.M.; Aboyeji, C.M.; Dunsin, O.; Simeon, V.T. Effects of biochar and poultry manure on soil characteristics and the yield of radish. Sci. Hortic. 2019, 243, 457-463. [CrossRef]

54. Dai, Y.; Zheng, H.; Jiang, Z.; Xing, B. Combined effects of biochar properties and soil conditions on plant growth: A meta-analysis. Sci. Total Environ. 2020, 713, 136635. [CrossRef]

55. Wang, D.; Li, C.; Parikh, S.J.; Scow, K.M. Impact of biochar on water retention of two agricultural soils-A multi-scale analysis. Geoderma 2019, 340, 185-191. [CrossRef]

56. Hardie, M.; Clothier, B.; Bound, S.; Oliver, G.; Close, D. Does biochar influence soil physical properties and soil water availability? Plant Soil 2014, 376, 347-361. [CrossRef]

57. Rogovska, N.; Laird, D.A.; Rathke, S.J.; Karlen, D.L. Biochar impact on Midwestern Mollisols and maize nutrient availability. Geoderma 2014, 230, 340-347. [CrossRef] 
58. Usowicz, B.; Lipiec, J.; Łukowski, M.; Marczewski, W.; Usowicz, J. The effect of biochar application on thermal properties and albedo of loess soil under grassland and fallow. Soil Tillage Res. 2016, 164, 45-51. [CrossRef]

59. Xiao, Q.; Zhu, L.-X.; Zhang, H.-P.; Li, X.-Y.; Shen, Y.-F.; Li, S.-Q. Soil amendment with biochar increases maize yields in a semi-arid region by improving soil quality and root growth. Crop Pasture Sci. 2016, 67, 495-507. [CrossRef]

60. Pratiwi, E.P.A.; Shinogi, Y. Rice husk biochar application to paddy soil and its effects on soil physical properties, plant growth, and methane emission. Paddy Water Environ. 2016, 14, 521-532. [CrossRef]

61. Obia, A.; Mulder, J.; Martinsen, V.; Cornelissen, G.; Børresen, T. In situ effects of biochar on aggregation, water retention and porosity in light-textured tropical soils. Soil Tillage Res. 2016, 155, 35-44. [CrossRef]

62. Liu, Z.; Dugan, B.; Masiello, C.A.; Barnes, R.T.; Gallagher, M.E.; Gonnermann, H. Impacts of biochar concentration and particle size on hydraulic conductivity and DOC leaching of biochar-sand mixtures. J. Hydrol. 2016, 533, 461-472. [CrossRef]

63. Chen, B.; Han, M.Y.; Peng, K.; Zhou, S.L.; Shao, L.; Wu, X.F.; Wei, W.D.; Liu, S.Y.; Li, Z.; Li, J.S.; et al. Global land-water nexus: Agricultural land and freshwater use embodied in worldwide supply chains. Sci. Total Environ. 2018, 613, 931-943. [CrossRef]

64. Fischer, B.M.C.; Manzoni, S.; Morillas, L.; Garcia, M.; Johnson, M.S.; Lyon, S.W. Improving agricultural water use efficiency with biochar-A synthesis of biochar effects on water storage and fluxes across scales. Sci. Total Environ. 2019, 657, 853-862. [CrossRef]

65. Basso, A.S.; Miguez, F.E.; Laird, D.A.; Horton, R.; Westgate, M. Assessing potential of biochar for increasing water-holding capacity of sandy soils. GCB Bioenergy 2013, 5, 132-143. [CrossRef]

66. Laghari, M.; Naidu, R.; Xiao, B.; Hu, Z.; Mirjat, M.S.; Hu, M.; Kandhro, M.N.; Chen, Z.; Guo, D.; Jogi, Q.; et al. Recent developments in biochar as an effective tool for agricultural soil management: A review. J. Sci. Food Agric. 2016, 96, 4840-4849. [CrossRef] [PubMed]

67. Obia, A.; Cornelissen, G.; Martinsen, V.; Smebye, A.B.; Mulder, J. Conservation tillage and biochar improve soil water content and moderate soil temperature in a tropical Acrisol. Soil Tillage Res. 2020, 197. [CrossRef]

68. Kinney, T.J.; Masiello, C.A.; Dugan, B.; Hockaday, W.C.; Dean, M.R.; Zygourakis, K.; Barnes, R.T. Hydrologic properties of biochars produced at different temperatures. Biomass Bioenergy 2012, 41, $34-43$. [CrossRef]

69. Lei, O.; Zhang, R. Effects of biochars derived from different feedstocks and pyrolysis temperatures on soil physical and hydraulic properties. J. Soils Sediments 2013, 13, 1561-1572. [CrossRef]

70. Rafiq, M.K.; Bachmann, R.T.; Rafiq, M.T.; Shang, Z.; Joseph, S.; Long, R. Influence of Pyrolysis Temperature on Physico-Chemical Properties of Corn Stover (Zea mays L.) Biochar and Feasibility for Carbon Capture and Energy Balance. PLoS ONE 2016, 11, e0156894. [CrossRef]

71. Gray, M.; Johnson, M.G.; Dragila, M.I.; Kleber, M. Water uptake in biochars: The roles of porosity and hydrophobicity. Biomass Bioenergy 2014, 61, 196-205. [CrossRef]

72. Mao, J.; Zhang, K.; Chen, B. Linking hydrophobicity of biochar to the water repellency and water holding capacity of biochar-amended soil. Environ. Pollut. 2019, 253, 779-789. [CrossRef]

73. Suliman, W.; Harsh, J.B.; Abu-Lail, N.I.; Fortuna, A.M.; Dallmeyer, I.; Garcia-Pérez, M. The role of biochar porosity and surface functionality in augmenting hydrologic properties of a sandy soil. Sci. Total Environ. 2017, 574, 139-147. [CrossRef]

74. Batista, E.M.C.C.; Shultz, J.; Matos, T.T.S.; Fornari, M.R.; Ferreira, T.M.; Szpoganicz, B.; De Freitas, R.A.; Mangrich, A.S. Effect of surface and porosity of biochar on water holding capacity aiming indirectly at preservation of the Amazon biome. Sci. Rep. 2018, 8, 1-9. [CrossRef]

75. Kameyama, K.; Miyamoto, T.; Iwata, Y. The Preliminary Study of Water-Retention Related Properties of Biochar Produced from Various Feedstock at Different Pyrolysis Temperatures. Materials 2019, 12, 1732. [CrossRef]

76. Barnes, R.T.; Gallagher, M.E.; Masiello, C.A.; Liu, Z.; Dugan, B. Biochar-induced changes in soil hydraulic conductivity and dissolved nutrient fluxes constrained by laboratory experiments. PLoS ONE 2014, 9. [CrossRef] [PubMed]

77. Aller, D.; Rathke, S.; Laird, D.; Cruse, R.; Hatfield, J. Impacts of fresh and aged biochars on plant available water and water use efficiency. Geoderma 2017, 307, 114-121. [CrossRef] 
78. Razzaghi, F.; Obour, P.B.; Arthur, E. Does biochar improve soil water retention? A systematic review and meta-analysis. Geoderma 2019. [CrossRef]

79. Marshall, J.; Muhlack, R.; Morton, B.J.; Dunnigan, L.; Chittleborough, D.; Kwong, C.W. Pyrolysis Temperature Effects on Biochar-Water Interactions and Application for Improved Water Holding Capacity in Vineyard Soils. Soil Syst. 2019, 3, 27. [CrossRef]

80. Zhang, X.; Cai, X. Climate change impacts on global agricultural land availability. Environ. Res. Lett. 2011, 6, 014014. [CrossRef]

81. Nguyen, T.T.N.; Xu, C.-Y.; Tahmasbian, I.; Che, R.; Xu, Z.; Zhou, X.; Wallace, H.M.; Bai, S.H. Effects of biochar on soil available inorganic nitrogen: A review and meta-analysis. Geoderma 2017, 288, 79-96. [CrossRef]

82. Gupta, R.K.; Hussain, A.; Sooch, S.S.; Kang, J.S.; Sharma, S.; Dheri, G.S. Rice straw biochar improves soil fertility, growth, and yield of rice-wheat system on a sandy loam soil. Exp. Agric. 2019, 56, 118-131. [CrossRef]

83. Khan, M.; Fatima, K.; Ahmad, R.; Younas, R.; Rizwan, M.; Azam, M.; Abadin, Z.; ul Ali, S. Comparative effect of mesquite biochar, farmyard manure, and chemical fertilizers on soil fertility and growth of onion (Allium cepa L.). Arab. J. Geosci. 2019, 12, 1-7. [CrossRef]

84. Borchard, N.; Schirrmann, M.; Cayuela, M.L.; Kammann, C.; Wrage-Mönnig, N.; Estavillo, J.M.; Fuertes-Mendizábal, T.; Sigua, G.; Spokas, K.; Ippolito, J.A.; et al. Biochar, soil and land-use interactions that reduce nitrate leaching and $\mathrm{N}_{2} \mathrm{O}$ emissions: A meta-analysis. Sci. Total Environ. 2019, 651, 2354-2364. [CrossRef]

85. Yao, Y.; Gao, B.; Zhang, M.; Inyang, M.; Zimmerman, A.R. Effect of biochar amendment on sorption and leaching of nitrate, ammonium, and phosphate in a sandy soil. Chemosphere 2012, 89, 1467-1471. [CrossRef]

86. Chen, Q.; Qin, J.; Sun, P.; Cheng, Z.; Shen, G. Cow dung-derived engineered biochar for reclaiming phosphate from aqueous solution and its validation as slow-release fertilizer in soil-crop system. J. Clean. Prod. 2018, 172, 2009-2018. [CrossRef]

87. Qiu, G.; Zhao, Y.; Wang, H.; Tan, X.; Chen, F.; Hu, X. Biochar synthesized via pyrolysis of Broussonetia papyrifera leaves: Mechanisms and potential applications for phosphate removal. Environ. Sci. Pollut. Res. 2019, 26, 6565-6575. [CrossRef] [PubMed]

88. Waqas, M.; Nizami, A.S.; Aburiazaiza, A.S.; Barakat, M.A.; Ismail, I.M.I.; Rashid, M.I. Optimization of food waste compost with the use of biochar. J. Environ. Manag. 2018, 216, 70-81. [CrossRef] [PubMed]

89. Solaiman, Z.M.; Abbott, L.K.; Murphy, D.V. Biochar phosphorus concentration dictates mycorrhizal colonisation, plant growth and soil phosphorus cycling. Sci. Rep. 2019, 9, 5062. [CrossRef] [PubMed]

90. Panwar, N.L.; Pawar, A.; Salvi, B.L. Comprehensive review on production and utilization of biochar. SN Appl. Sci. 2019, 1, 168. [CrossRef]

91. Jiang, Z.; Lian, F.; Wang, Z.; Xing, B. The role of biochars in sustainable crop production and soil resiliency. J. Exp. Bot. 2020, 71, 520-542. [CrossRef]

92. Xiao, X.; Chen, B.; Chen, Z.; Zhu, L.; Schnoor, J.L. Insight into Multiple and Multilevel Structures of Biochars and Their Potential Environmental Applications: A Critical Review. Environ. Sci. Technol. 2018, 52, 5027-5047. [CrossRef]

93. Liu, W.-J.; Jiang, H.; Yu, H.-Q. Development of Biochar-Based Functional Materials: Toward a Sustainable Platform Carbon Material. Chem. Rev. 2015, 115, 12251-12285. [CrossRef]

94. Billa, S.F.; Angwafo, T.E.; Ngome, A.F. Agro-environmental characterization of biochar issued from crop wastes in the humid forest zone of Cameroon. Int. J. Recycl. Org. Waste Agric. 2019, 8. [CrossRef]

95. Gao, S.; DeLuca, T.H. Wood biochar impacts soil phosphorus dynamics and microbial communities in organically-managed croplands. Soil Biol. Biochem. 2018, 126, 144-150. [CrossRef]

96. Zhang, R.; Zhang, Y.; Song, L.; Song, X.; Hänninen, H.; Wu, J. Biochar enhances nut quality of Torreya grandis and soil fertility under simulated nitrogen deposition. For. Ecol. Manag. 2017, 391, 321-329. [CrossRef]

97. Liu, Q.; Zhang, Y.; Liu, B.; Amonette, J.E.; Lin, Z.; Liu, G.; Ambus, P.; Xie, Z. How does biochar influence soil N cycle? A meta-analysis. Plant Soil 2018, 426, 211-225. [CrossRef]

98. Joseph, U.E.; Toluwase, A.O.; Kehinde, E.O.; Omasan, E.E.; Tolulope, A.Y.; George, O.O.; Zhao, C.; Hongyan, W. Effect of biochar on soil structure and storage of soil organic carbon and nitrogen in the aggregate fractions of an Albic soil. Arch. Agron. Soil Sci. 2019, 1-12. [CrossRef]

99. Khademalrasoul, A.; Kuhn, N.J.; Elsgaard, L.; Hu, Y.; Iversen, B.V.; Heckrath, G. Short-term Effects of Biochar Application on Soil Loss During a Rainfall-Runoff Simulation. Soil Sci. 2019, 184, 17-24. [CrossRef] 
100. Soinne, H.; Hovi, J.; Tammeorg, P.; Turtola, E. Effect of biochar on phosphorus sorption and clay soil aggregate stability. Geoderma 2014, 219, 162-167. [CrossRef]

101. Lin, Y.; Munroe, P.; Joseph, S.; Kimber, S.; Van Zwieten, L. Nanoscale organo-mineral reactions of biochars in ferrosol: An investigation using microscopy. Plant Soil 2012, 357, 369-380. [CrossRef]

102. Jien, S.-H.; Wang, C.-S. Effects of biochar on soil properties and erosion potential in a highly weathered soil. Catena 2013, 110, 225-233. [CrossRef]

103. Lee, S.S.; Shah, H.S.; Awad, Y.M.; Kumar, S.; Ok, Y.S. Synergy effects of biochar and polyacrylamide on plants growth and soil erosion control. Environ. Earth Sci. 2015, 74, 2463-2473. [CrossRef]

104. Inyang, M.; Dickenson, E. The potential role of biochar in the removal of organic and microbial contaminants from potable and reuse water: A review. Chemosphere 2015, 134, 232-240. [CrossRef]

105. Shi, R.; Ni, N.; Nkoh, J.N.; Li, J.; Xu, R.; Qian, W. Beneficial dual role of biochars in inhibiting soil acidification resulting from nitrification. Chemosphere 2019, 234, 43-51. [CrossRef]

106. Wang, J.; Sun, N.; Xu, M.; Wang, S.; Zhang, J.; Cai, Z.; Cheng, Y. The influence of long-term animal manure and crop residue application on abiotic and biotic $\mathrm{N}$ immobilization in an acidified agricultural soil. Geoderma 2019, 337, 710-717. [CrossRef]

107. Conyers, M.K.; Mullen, C.L.; Scott, B.J.; Poile, G.J.; Braysher, B.D. Long-term benefits of limestone applications to soil properties and to cereal crop yields in southern and central New South Wales. Aust. J. Exp. Agric. 2003, 43, 71-78. [CrossRef]

108. Guodao, Y.J.L.L.L. Research on Soil Acidification and Acidic Soil's Melioration. J. South China Univ. Trop. Agric. 2006, 1, 21-28.

109. Zhang, H.; Dao, T.H.; Basta, N.T.; Dayton, E.A.; Daniel, T.C. Remediation techniques for manure nutrient loaded soils. Am. Soc. Agric. Biol. Eng. 2006. [CrossRef]

110. Palviainen, M.; Berninger, F.; Bruckman, V.J.; Köster, K.; de Assumpção, C.R.M.; Aaltonen, H.; Makita, N.; Mishra, A.; Kulmala, L.; Adamczyk, B.; et al. Effects of biochar on carbon and nitrogen fluxes in boreal forest soil. Plant Soil 2018, 425, 71-85. [CrossRef]

111. Wu, D.; Senbayram, M.; Zang, H.; Ugurlar, F.; Aydemir, S.; Brüggemann, N.; Kuzyakov, Y.; Bol, R.; Blagodatskaya, E. Effect of biochar origin and soil $\mathrm{pH}$ on greenhouse gas emissions from sandy and clay soils. Appl. Soil Ecol. 2018, 129, 121-127. [CrossRef]

112. Si, L.; Xie, Y.; Ma, Q.; Wu, L. The Short-Term Effects of Rice Straw Biochar, Nitrogen and Phosphorus Fertilizer on Rice Yield and Soil Properties in a Cold Waterlogged Paddy Field. Sustainability 2018, 10, 537. [CrossRef]

113. Xu, R.; Zhao, A.; Yuan, J.; Jiang, J. pH buffering capacity of acid soils from tropical and subtropical regions of China as influenced by incorporation of crop straw biochars. J. Soils Sediments 2012, 12, 494-502. [CrossRef]

114. Novak, J.M.; Busscher, W.J.; Laird, D.L.; Ahmedna, M.; Watts, D.W.; Niandou, M.A.S. Impact of biochar amendment on fertility of a southeastern coastal plain soil. Soil Sci. 2009, 174, 105-112. [CrossRef]

115. Jeffery, S.; Verheijen, F.G.A.; van der Velde, M.; Bastos, A.C. A quantitative review of the effects of biochar application to soils on crop productivity using meta-analysis. Agric. Ecosyst. Environ. 2011, 144, 175-187. [CrossRef]

116. Verheijen, F.; Jeffery, S.; Bastos, A.C.; Van der Velde, M.; Diafas, I. Biochar Application to Soils—A Critical Scientific Review of Effects on Soil Properties, Processes and Functions; European Commission Publication Office: Luxembourg, 2010; Volume 24099, p. 162.

117. Qian, L.; Chen, B. Dual role of biochars as adsorbents for aluminum: The effects of oxygen-containing organic components and the scattering of silicate particles. Environ. Sci. Technol. 2013, 47, 8759-8768. [CrossRef]

118. Fidel, R.B.; Laird, D.A.; Thompson, M.L.; Lawrinenko, M. Characterization and quantification of biochar alkalinity. Chemosphere 2017, 167, 367-373. [CrossRef] [PubMed]

119. Zhao, H.; Yu, L.; Yu, M.; Afzal, M.; Dai, Z.; Brookes, P.; Xu, J. Nitrogen combined with biochar changed the feedback mechanism between soil nitrification and Cd availability in an acidic soil. J. Hazard. Mater. 2019, 390, 121631. [CrossRef]

120. Gondek, K.; Mierzwa-Hersztek, M.; Kopeć, M.; Sikora, J.; Głąb, T.; Szczurowska, K. Influence of Biochar Application on Reduced Acidification of Sandy Soil, Increased Cation Exchange Capacity, and the Content of Available Forms of K, Mg, and P. Pol. J. Environ. Stud. 2019, 28, 1-9. [CrossRef]

121. Taghizadeh-Toosi, A.; Clough, T.J.; Sherlock, R.R.; Condron, L.M. Biochar adsorbed ammonia is bioavailable. Plant Soil 2012, 350, 57-69. [CrossRef] 
122. Zhang, Y.; Chen, H.; Ji, G.; Zhang, Y.; Xiang, J.; Anwar, S.; Zhu, D. Effect of Rice-straw Biochar Application on Rice (Oryza sativa L.) Root Growth and Nitrogen Utilization in Acidified Paddy Soil. Int. J. Agric. Biol. 2018, 20, 2529-2536.

123. Shi, R.; Li, J.; Jiang, J.; Kamran, M.A.; Xu, R.; Qian, W. Incorporation of corn straw biochar inhibited the re-acidification of four acidic soils derived from different parent materials. Environ. Sci. Pollut. Res. 2018, 25, 9662-9672. [CrossRef]

124. Shi, R.; Hong, Z.; Li, J.; Jiang, J.; Kamran, M.A.; Xu, R.; Qian, W. Peanut straw biochar increases the resistance of two Ultisols derived from different parent materials to acidification: A mechanism study. J. Environ. Manag. 2018, 210, 171-179. [CrossRef]

125. Wang, J.; Zhang, B.; Tian, Y.; Zhang, H.; Cheng, Y.; Zhang, J. A soil management strategy for ameliorating soil acidification and reducing nitrification in tea plantations. Eur. J. Soil Biol. 2018, 88, 36-40. [CrossRef]

126. Mierzwa-Hersztek, M.; Gondek, K.; Klimkowicz-Pawlas, A.; Baran, A.; Bajda, T. Sewage sludge biochars management-Ecotoxicity, mobility of heavy metals, and soil microbial biomass. Environ. Toxicol. Chem. 2018, 37, 1197-1207. [CrossRef]

127. Cross, A.; Sohi, S.P. The priming potential of biochar products in relation to labile carbon contents and soil organic matter status. Soil Biol. Biochem. 2011, 43, 2127-2134. [CrossRef]

128. Zimmerman, A.R.; Gao, B.; Ahn, M.-Y. Positive and negative carbon mineralization priming effects among a variety of biochar-amended soils. Soil Biol. Biochem. 2011, 43, 1169-1179. [CrossRef]

129. Zhao, S.; Ta, N.; Li, Z.; Yang, Y.; Zhang, X.; Liu, D.; Zhang, A.; Wang, X. Varying pyrolysis temperature impacts application effects of biochar on soil labile organic carbon and humic fractions. Appl. Soil Ecol. 2018, 123, 484-493. [CrossRef]

130. Luo, Y.; Durenkamp, M.; De Nobili, M.; Lin, Q.; Brookes, P.C. Short term soil priming effects and the mineralisation of biochar following its incorporation to soils of different $\mathrm{pH}$. Soil Biol. Biochem. 2011, 43, 2304-2314. [CrossRef]

131. Li, Y.; Zhou, C.; Qiu, Y.; Tigabu, M.; Ma, X. Effects of biochar and litter on carbon and nitrogen mineralization and soil microbial community structure in a China fir plantation. J. For. Res. 2019, 30, 1913-1923. [CrossRef]

132. Cui, J.; Ge, T.; Kuzyakov, Y.; Nie, M.; Fang, C.; Tang, B.; Zhou, C. Interactions between biochar and litter priming: A three-source $14 \mathrm{C}$ and $813 \mathrm{C}$ partitioning study. Soil Biol. Biochem. 2017, 104, 49-58. [CrossRef]

133. Maestrini, B.; Herrmann, A.M.; Nannipieri, P.; Schmidt, M.W.I.; Abiven, S. Ryegrass-derived pyrogenic organic matter changes organic carbon and nitrogen mineralization in a temperate forest soil. Soil Biol. Biochem. 2014, 69, 291-301. [CrossRef]

134. Ventura, M.; Alberti, G.; Panzacchi, P.; Delle Vedove, G.; Miglietta, F.; Tonon, G. Biochar mineralization and priming effect in a poplar short rotation coppice from a 3-year field experiment. Biol. Fertil. Soils 2019, 55, 67-78. [CrossRef]

135. Kuzyakov, Y.; Friedel, J.K.; Stahr, K. Review of mechanisms and quantification of priming effects. Soil Biol. Biochem. 2000, 32, 1485-1498. [CrossRef]

136. De Figueiredo, C.C.; Farias, W.M.; de Melo, B.A.; Chagas, J.K.M.; Vale, A.T.; Coser, T.R. Labile and stable pools of organic matter in soil amended with sewage sludge biochar. Arch. Agron. Soil Sci. 2019, 65, 770-781. [CrossRef]

137. Ji, X.; Abakumov, E.; Xie, X.; Wei, D.; Tang, R.; Ding, J.; Cheng, Y.; Chen, J. Preferential Alternatives to Returning All Crop Residues as Biochar to the Crop Field? A Three-Source 13C and 14C Partitioning Study. J. Agric. Food Chem. 2019, 67, 11322-11330. [CrossRef] [PubMed]

138. Bista, P.; Ghimire, R.; Machado, S.; Pritchett, L. Biochar Effects on Soil Properties and Wheat Biomass vary with Fertility Management. Agronomy 2019, 9, 623. [CrossRef]

139. Schofield, H.K.; Pettitt, T.R.; Tappin, A.D.; Rollinson, G.K.; Fitzsimons, M.F. Biochar incorporation increased nitrogen and carbon retention in a waste-derived soil. Sci. Total Environ. 2019, 690, 1228-1236. [CrossRef] [PubMed]

140. Andrés, P.; Rosell-Melé, A.; Colomer-Ventura, F.; Denef, K.; Cotrufo, M.F.; Riba, M.; Alcañiz, J.M. Belowground biota responses to maize biochar addition to the soil of a Mediterranean vineyard. Sci. Total Environ. 2019, 660, 1522-1532. [CrossRef] [PubMed]

141. Orlova, N.; Abakumov, E.; Orlova, E.; Yakkonen, K.; Shahnazarova, V. Soil organic matter alteration under biochar amendment: Study in the incubation experiment on the Podzol soils of the Leningrad region (Russia). J. Soils Sediments 2019, 19, 2708-2716. [CrossRef] 
142. Kammoun-Rigane, M.; Hlel, H.; Medhioub, K. Biochars Induced Changes in the Physicochemical Characteristics of Technosols: Effects of Feedstock and Pyrolysis Temperature. In Recent Advances in Geo-Environmental Engineering, Geomechanics and Geotechnics, and Geohazards; Springer: Berlin/Heidelberg, Germany, 2019; pp. 109-111.

143. Raiesi, F.; Khadem, A. Short-term effects of maize residue biochar on kinetic and thermodynamic parameters of soil $\beta$-glucosidase. Biochar 2019, 1, 213-227. [CrossRef]

144. Lehman, R.; Cambardella, C.; Stott, D.; Acosta-Martinez, V.; Manter, D.; Buyer, J.; Maul, J.; Smith, J.; Collins, H.; Halvorson, J.; et al. Understanding and Enhancing Soil Biological Health: The Solution for Reversing Soil Degradation. Sustainability 2015, 7, 988-1027. [CrossRef]

145. Morrow, J.G.; Huggins, D.R.; Carpenter-Boggs, L.A.; Reganold, J.P. Evaluating Measures to Assess Soil Health in Long-Term Agroecosystem Trials. Soil Sci. Soc. Am. J. 2016, 80, 450. [CrossRef]

146. Muhammad, N.; Dai, Z.; Xiao, K.; Meng, J.; Brookes, P.C.; Liu, X.; Wang, H.; Wu, J.; Xu, J. Changes in microbial community structure due to biochars generated from different feedstocks and their relationships with soil chemical properties. Geoderma 2014, 226, 270-278. [CrossRef]

147. Wang, D.; Zhang, N.; Tang, H.; Adams, J.M.; Sun, B.; Liang, Y. Straw biochar strengthens the life strategies and network of rhizosphere fungi in manure fertilized soils. Soil Ecol. Lett. 2019, 1, 72-84. [CrossRef]

148. Zhang, L.; Jing, Y.; Xiang, Y.; Zhang, R.; Lu, H. Responses of soil microbial community structure changes and activities to biochar addition: A meta-analysis. Sci. Total Environ. 2018, 643, 926-935. [CrossRef] [PubMed]

149. Palansooriya, K.N.; Wong, J.T.F.; Hashimoto, Y.; Huang, L.; Rinklebe, J.; Chang, S.X.; Bolan, N.; Wang, H.; Ok, Y.S. Response of microbial communities to biochar-amended soils: A critical review. Biochar 2019, 1, 3-22. [CrossRef]

150. Song, D.; Xi, X.; Zheng, Q.; Liang, G.; Zhou, W.; Wang, X. Soil nutrient and microbial activity responses to two years after maize straw biochar application in a calcareous soil. Ecotoxicol. Environ. Saf. 2019, 180, 348-356. [CrossRef] [PubMed]

151. Chen, J.; Sun, X.; Zheng, J.; Zhang, X.; Liu, X.; Bian, R.; Li, L.; Cheng, K.; Zheng, J.; Pan, G. Biochar amendment changes temperature sensitivity of soil respiration and composition of microbial communities 3 years after incorporation in an organic carbon-poor dry cropland soil. Biol. Fertil. Soils 2018, 54, 175-188. [CrossRef]

152. Liu, Z.; Zhu, M.; Wang, J.; Liu, X.; Guo, W.; Zheng, J.; Bian, R.; Wang, G.; Zhang, X.; Cheng, K.; et al. The responses of soil organic carbon mineralization and microbial communities to fresh and aged biochar soil amendments. GCB Bioenergy 2019, 11, 1408-1420. [CrossRef]

153. Luo, Y.; Dungait, J.A.J.; Zhao, X.; Brookes, P.C.; Durenkamp, M.; Li, G.; Lin, Q. Pyrolysis temperature during biochar production alters its subsequent utilization by microorganisms in an acid arable soil. Land Degrad. Dev. 2018, 29, 2183-2188. [CrossRef]

154. Du, Y.; Wu, J.; Anane, P.-S.; Wu, Y.; Wang, C.; Liu, S. Effects of Different Biochars on Physicochemical Properties and Fungal Communities of Black Soil. Pol. J. Environ. Stud. 2019, 28, 3125-3132. [CrossRef]

155. Bonanomi, G.; Ippolito, F.; Cesarano, G.; Vinale, F.; Lombardi, N.; Crasto, A.; Woo, S.L.; Scala, F. Biochar chemistry defined by 13C-CPMAS NMR explains opposite effects on soilborne microbes and crop plants. Appl. Soil Ecol. 2018, 124, 351-361. [CrossRef]

156. Zhang, Y.; Liu, Y.; Zhang, G.; Guo, X.; Sun, Z.; Li, T. The Effects of Rice Straw and Biochar Applications on the Microbial Community in a Soil with a History of Continuous Tomato Planting History. Agronomy 2018, 8, 65. [CrossRef]

157. Paymaneh, Z.; Gryndler, M.; Konvalinková, T.; Benada, O.; Borovička, J.; Bukovská, P.; Püschel, D.; Řezáčová, V.; Sarcheshmehpour, M.; Jansa, J. Soil Matrix Determines the Outcome of Interaction Between Mycorrhizal Symbiosis and Biochar for Andropogon gerardii Growth and Nutrition. Front. Microbiol. 2018, 9, 2862. [CrossRef]

158. Dangi, S.; Gao, S.; Duan, Y.; Wang, D. Soil microbial community structure affected by biochar and fertilizer sources. Appl. Soil Ecol. 2019. [CrossRef]

159. Li, Y.; Yang, Y.; Shen, F.; Tian, D.; Zeng, Y.; Yang, G.; Zhang, Y.; Deng, S. Partitioning biochar properties to elucidate their contributions to bacterial and fungal community composition of purple soil. Sci. Total Environ. 2019, 648, 1333-1341. [CrossRef] [PubMed]

160. Zheng, N.; Yu, Y.; Shi, W.; Yao, H. Biochar suppresses $\mathrm{N}_{2} \mathrm{O}$ emissions and alters microbial communities in an acidic tea soil. Environ. Sci. Pollut. Res. 2019, 1-10. [CrossRef] [PubMed] 
161. Dai, Z.; Enders, A.; Rodrigues, J.L.M.; Hanley, K.L.; Brookes, P.C.; Xu, J.; Lehmann, J. Soil fungal taxonomic and functional community composition as affected by biochar properties. Soil Biol. Biochem. 2018, 126, 159-167. [CrossRef]

162. Nie, C.; Yang, X.; Niazi, N.K.; Xu, X.; Wen, Y.; Rinklebe, J.; Ok, Y.S.; Xu, S.; Wang, H. Impact of sugarcane bagasse-derived biochar on heavy metal availability and microbial activity: A field study. Chemosphere 2018, 200, 274-282. [CrossRef] [PubMed]

163. Liu, Y.; Zhu, J.; Ye, C.; Zhu, P.; Ba, Q.; Pang, J.; Shu, L. Effects of biochar application on the abundance and community composition of denitrifying bacteria in a reclaimed soil from coal mining subsidence area. Sci. Total Environ. 2018, 625, 1218-1224. [CrossRef]

164. Yu, J.; Deem, L.M.; Crow, S.E.; Deenik, J.L.; Penton, C.R. Biochar application influences microbial assemblage complexity and composition due to soil and bioenergy crop type interactions. Soil Biol. Biochem. 2018, 117, 97-107. [CrossRef]

165. Liu, X.; Li, J.; Yu, L.; Pan, H.; Liu, H.; Liu, Y.; Di, H.; Li, Y.; Xu, J. Simultaneous measurement of bacterial abundance and composition in response to biochar in soybean field soil using $16 \mathrm{~S}$ rRNA gene sequencing. Land Degrad. Dev. 2018, 29, 2172-2182. [CrossRef]

166. Liu, X.; Zhou, J.; Chi, Z.; Zheng, J.; Li, L.; Zhang, X.; Zheng, J.; Cheng, K.; Bian, R.; Pan, G. Biochar provided limited benefits for rice yield and greenhouse gas mitigation six years following an amendment in a fertile rice paddy. Catena 2019, 179, 20-28. [CrossRef]

167. Nguyen, T.T.N.; Wallace, H.M.; Xu, C.-Y.; (Van) Zwieten, L.; Weng, Z.H.; Xu, Z.; Che, R.; Tahmasbian, I.; $\mathrm{Hu}, \mathrm{H}$. -W.; Bai, S.H. The effects of short term, long term and reapplication of biochar on soil bacteria. Sci. Total Environ. 2018, 636, 142-151. [CrossRef]

168. Cole, E.J.; Zandvakili, O.R.; Blanchard, J.; Xing, B.; Hashemi, M.; Etemadi, F. Investigating responses of soil bacterial community composition to hardwood biochar amendment using high-throughput PCR sequencing. Appl. Soil Ecol. 2019, 136, 80-85. [CrossRef]

169. Song, Y.; Li, X.; Xu, M.; Jiao, W.; Bian, Y.; Yang, X.; Gu, C.; Wang, F.; Jiang, X. Does Biochar Induce Similar Successions of Microbial Community Structures Among Different Soils? Bull. Environ. Contam. Toxicol. 2019, 103, 642-650. [CrossRef] [PubMed]

170. Ge, X.; Cao, Y.; Zhou, B.; Wang, X.; Yang, Z.; Li, M.-H. Biochar addition increases subsurface soil microbial biomass but has limited effects on soil $\mathrm{CO}_{2}$ emissions in subtropical moso bamboo plantations. Appl. Soil Ecol. 2019, 142, 155-165. [CrossRef]

171. Han Weng, Z.; Van Zwieten, L.; Singh, B.P.; Tavakkoli, E.; Joseph, S.; Macdonald, L.M.; Rose, T.J.; Rose, M.T.; Kimber, S.W.L.; Morris, S.; et al. Biochar built soil carbon over a decade by stabilizing rhizodeposits. Nat. Clim. Chang. 2017, 7, 371-376. [CrossRef]

172. Brändli, R.C.; Hartnik, T.; Henriksen, T.; Cornelissen, G. Sorption of native polyaromatic hydrocarbons (PAH) to black carbon and amended activated carbon in soil. Chemosphere 2008, 73, 1805-1810. [CrossRef]

173. Jonker, M.T.O.; van der Heijden, S.A.; Kreitinger, J.P.; Hawthorne, S.B. Predicting PAH bioaccumulation and toxicity in earthworms exposed to manufactured gas plant soils with solid-phase microextraction. Environ. Sci. Technol. 2007, 41, 7472-7478. [CrossRef]

174. Kreitinger, J.P.; Quĩones-Rivera, A.; Neuhauser, E.F.; Alexander, M.; Hawthorne, S.B. Supercritical carbon dioxide extraction as a predictor of polycyclic aromatic hydrocarbon bioaccumulation and toxicity by earthworms in manufactured-gas plant site soils. Environ. Toxicol. Chem. Int. J. 2007, 26, 1809-1817. [CrossRef]

175. O'Connor, D.; Peng, T.; Zhang, J.; Tsang, D.C.W.; Alessi, D.S.; Shen, Z.; Bolan, N.S.; Hou, D. Biochar application for the remediation of heavy metal polluted land: A review of in situ field trials. Sci. Total Environ. 2018, 619, 815-826. [CrossRef]

176. He, L.; Zhong, H.; Liu, G.; Dai, Z.; Brookes, P.C.; Xu, J. Remediation of heavy metal contaminated soils by biochar: Mechanisms, potential risks and applications in China. Environ. Pollut. 2019, 252, 846-855. [CrossRef]

177. Beesley, L.; Moreno-Jiménez, E.; Gomez-Eyles, J.L. Effects of biochar and greenwaste compost amendments on mobility, bioavailability and toxicity of inorganic and organic contaminants in a multi-element polluted soil. Environ. Pollut. 2010, 158, 2282-2287. [CrossRef] 
178. Cui, L.; Pan, G.; Li, L.; Bian, R.; Liu, X.; Yan, J.; Quan, G.; Ding, C.; Chen, T.; Liu, Y. Continuous immobilization of cadmium and lead in biochar amended contaminated paddy soil: A five-year field experiment. Ecol. Eng. 2016, 93, 1-8. [CrossRef]

179. Lomaglio, T.; Hattab-Hambli, N.; Miard, F.; Lebrun, M.; Nandillon, R.; Trupiano, D.; Scippa, G.S.; Gauthier, A.; Motelica-Heino, M.; Bourgerie, S. Cd, $\mathrm{Pb}$, and $\mathrm{Zn}$ mobility and (bio) availability in contaminated soils from a former smelting site amended with biochar. Environ. Sci. Pollut. Res. 2018, 25, 25744-25756. [CrossRef] [PubMed]

180. De Figueiredo, C.C.; Chagas, J.K.M.; da Silva, J.; Paz-Ferreiro, J. Short-term effects of a sewage sludge biochar amendment on total and available heavy metal content of a tropical soil. Geoderma 2019, 344, 31-39. [CrossRef]

181. Nzediegwu, C.; Prasher, S.; Elsayed, E.; Dhiman, J.; Mawof, A.; Patel, R. Effect of biochar on heavy metal accumulation in potatoes from wastewater irrigation. J. Environ. Manag. 2019, 232, 153-164. [CrossRef] [PubMed]

182. Wang, Y.; Zhong, B.; Shafi, M.; Ma, J.; Guo, J.; Wu, J.; Ye, Z.; Liu, D.; Jin, H. Effects of biochar on growth, and heavy metals accumulation of moso bamboo (Phyllostachy pubescens), soil physical properties, and heavy metals solubility in soil. Chemosphere 2019, 219, 510-516. [CrossRef] [PubMed]

183. Kamran, M.; Malik, Z.; Parveen, A.; Huang, L.; Riaz, M.; Bashir, S.; Mustafa, A.; Abbasi, G.H.; Xue, B.; Ali, U. Ameliorative effects of biochar on rapeseed (Brassica napus L.) growth and heavy metal immobilization in soil irrigated with untreated wastewater. J. Plant Growth Regul. 2020, 39, 266-281. [CrossRef]

184. Ghori, S.A.; Gul, S.; Tahir, S.; Sohail, M.; Batool, S.; Shahwani, M.N.; Bano, G. Wood-derived biochar influences nutrient use efficiency of heavy metals in spinach (Spinacia oleracea) under groundwater and wastewater irrigation. J. Environ. Eng. Landsc. Manag. 2019, 27, 144-152. [CrossRef]

185. Antonangelo, J.A.; Zhang, H. Heavy metal phytoavailability in a contaminated soil of northeastern Oklahoma as affected by biochar amendment. Environ. Sci. Pollut. Res. 2019, 26, 33582-33593. [CrossRef]

186. Cui, L.; Noerpel, M.R.; Scheckel, K.G.; Ippolito, J.A. Wheat straw biochar reduces environmental cadmium bioavailability. Environ. Int. 2019, 126, 69-75. [CrossRef]

187. Shen, Z.; Zhang, J.; Hou, D.; Tsang, D.C.W.; Ok, Y.S.; Alessi, D.S. Synthesis of MgO-coated corncob biochar and its application in lead stabilization in a soil washing residue. Environ. Int. 2019, 122, 357-362. [CrossRef]

188. Qian, T.-T.; Wu, P.; Qin, Q.-Y.; Huang, Y.-N.; Wang, Y.-J.; Zhou, D.-M. Screening of wheat straw biochars for the remediation of soils polluted with $\mathrm{Zn}$ (II) and Cd (II). J. Hazard. Mater. 2019, 362, 311-317. [CrossRef] [PubMed]

189. Novak, J.M.; Ippolito, J.A.; Watts, D.W.; Sigua, G.C.; Ducey, T.F.; Johnson, M.G. Biochar compost blends facilitate switchgrass growth in mine soils by reducing Cd and Zn bioavailability. Biochar 2019, 1, 97-114. [CrossRef]

190. Derakhshan-Nejad, Z.; Jung, M.C. Remediation of multi-metal contaminated soil using biochars from rice husk and maple leaves. J. Mater. Cycles Waste Manag. 2019, 21, 457-468. [CrossRef]

191. Andrey, G.; Rajput, V.; Tatiana, M.; Saglara, M.; Svetlana, S.; Igor, K.; Grigoryeva, T.V.; Vasily, C.; Iraida, A.; Vladislav, Z. The role of biochar-microbe interaction in alleviating heavy metal toxicity in Hordeum vulgare $\mathrm{L}$. grown in highly polluted soils. Appl. Geochem. 2019, 104, 93-101. [CrossRef]

192. Schaeffer, S.; Koepke, T.; Dhingra, A. Tobacco: A Model Plant for Understanding the Mechanism of Abiotic Stress Tolerance. In Improving Crop Resistance to Abiotic Stress; Wiley-VCH Verlag GmbH \& Co. KGaA: Weinheim, Germany, 2012; Volume 2, pp. 1169-1201.

193. Dahlawi, S.; Naeem, A.; Rengel, Z.; Naidu, R. Biochar application for the remediation of salt-affected soils: Challenges and opportunities. Sci. Total Environ. 2018, 625, 320-335.

194. Lashari, M.S.; Liu, Y.; Li, L.; Pan, W.; Fu, J.; Pan, G.; Zheng, J.; Zheng, J.; Zhang, X.; Yu, X. Effects of amendment of biochar-manure compost in conjunction with pyroligneous solution on soil quality and wheat yield of a salt-stressed cropland from Central China Great Plain. Field Crop. Res. 2013, 144, 113-118. [CrossRef]

195. Akhtar, S.S.; Andersen, M.N.; Liu, F. Biochar mitigates salinity stress in potato. J. Agron. Crop Sci. 2015, 201, 368-378. [CrossRef]

196. Akhtar, S.S.; Andersen, M.N.; Liu, F. Residual effects of biochar on improving growth, physiology and yield of wheat under salt stress. Agric. Water Manag. 2015, 158, 61-68. [CrossRef] 
197. Akhtar, S.S.; Andersen, M.N.; Naveed, M.; Zahir, Z.A.; Liu, F. Interactive effect of biochar and plant growth-promoting bacterial endophytes on ameliorating salinity stress in maize. Funct. Plant Biol. 2015, 42, 770-781. [CrossRef]

198. Lashari, M.S.; Ye, Y.; Ji, H.; Li, L.; Kibue, G.W.; Lu, H.; Zheng, J.; Pan, G. Biochar-manure compost in conjunction with pyroligneous solution alleviated salt stress and improved leaf bioactivity of maize in a saline soil from central China: A 2-year field experiment. J. Sci. Food Agric. 2015, 95, 1321-1327. [CrossRef]

199. Zhang, J.; Bai, Z.; Huang, J.; Hussain, S.; Zhao, F.; Zhu, C.; Zhu, L.; Cao, X.; Jin, Q. Biochar alleviated the salt stress of induced saline paddy soil and improved the biochemical characteristics of rice seedlings differing in salt tolerance. Soil Tillage Res. 2019, 195, 104372. [CrossRef]

200. Abd El-Mageed, T.A.; Rady, M.M.; Taha, R.S.; Abd El Azeam, S.; Simpson, C.R.; Semida, W.M. Effects of integrated use of residual sulfur-enhanced biochar with effective microorganisms on soil properties, plant growth and short-term productivity of Capsicum annuum under salt stress. Sci. Hortic. 2020, 261, 108930. [CrossRef]

201. Mingyi, H.; Zhang, Z.; Zhu, C.; Zhai, Y.; Peirong, L. Effect of biochar on sweet corn and soil salinity under conjunctive irrigation with brackish water in coastal saline soil. Sci. Hortic. 2019, 250, 405-413. [CrossRef]

202. Hafeez, F.; Rizwan, M.; Saqib, M.; Yasmeen, T.; Ali, S.; Abbas, T.; Zia-ur-Rehman, M.; Qayyum, M. Residual effect of biochar on growth, antioxidant defence and cadmium (Cd) accumulation in rice in a $\mathrm{Cd}$ contaminated saline soil. Pak. J. Agric. Sci. 2018, 56. [CrossRef]

203. Nikpour-Rashidabad, N.; Tavasolee, A.; Torabian, S.; Farhangi-Abriz, S. The effect of biochar on the physiological, morphological and anatomical characteristics of mung bean roots after exposure to salt stress. Arch. Biol. Sci. 2019, 71, 14. [CrossRef]

204. Aboshanab, W.; Osman, M.; Nessim, A.; Mohsen, A.; Elsaka, M. Evaluation of Biochar as a Soil Amendment for Alleviating the Harmful Effect of Salinity on Vigna unguiculata (L.) Walp. Egipt. J. Bot. 2019, 59, 617-631.

205. Jaiswal, A.K.; Frenkel, O.; Tsechansky, L.; Elad, Y.; Graber, E.R. Immobilization and deactivation of pathogenic enzymes and toxic metabolites by biochar: A possible mechanism involved in soilborne disease suppression. Soil Biol. Biochem. 2018, 121, 59-66. [CrossRef]

206. Harel, Y.M.; Elad, Y.; Rav-David, D.; Borenstein, M.; Shulchani, R.; Lew, B.; Graber, E.R. Biochar mediates systemic response of strawberry to foliar fungal pathogens. Plant Soil 2012, 357, 245-257. [CrossRef]

207. Kumar, A.; Elad, Y.; Tsechansky, L.; Abrol, V.; Lew, B.; Offenbach, R.; Graber, E.R. Biochar potential in intensive cultivation of Capsicum annuum L.(sweet pepper): Crop yield and plant protection. J. Sci. Food Agric. 2018, 98, 495-503. [CrossRef]

208. Jaiswal, A.K.; Elad, Y.; Paudel, I.; Graber, E.R.; Cytryn, E.; Frenkel, O. Linking the belowground microbial composition, diversity and activity to soilborne disease suppression and growth promotion of tomato amended with biochar. Sci. Rep. 2017, 7, 44382. [CrossRef]

209. Knox, O.G.G.; Oghoro, C.O.; Burnett, F.J.; Fountaine, J.M. Biochar increases soil pH, but is as ineffective as liming at controlling clubroot. J. Plant Pathol. 2015, 97, 149-152.

210. Bonanomi, G.; Ippolito, F.; Scala, F. A “black” future for plant pathology? Biochar as a new soil amendment for controlling plant diseases. J. Plant Pathol. 2015, 97, 223-234.

211. Jaiswal, A.K.; Graber, E.R.; Elad, Y.; Frenkel, O. Biochar as a management tool for soilborne diseases affecting early stage nursery seedling production. Crop Prot. 2019, 120, 34-42. [CrossRef]

212. Lechenet, M.; Dessaint, F.; Py, G.; Makowski, D.; Munier-Jolain, N. Reducing pesticide use while preserving crop productivity and profitability on arable farms. Nat. Plants 2017, 3, 17008. [CrossRef] [PubMed]

213. Elijah, O.; Rahman, T.A.; Orikumhi, I.; Leow, C.Y.; Hindia, M.H.D.N. An Overview of Internet of Things (IoT) and Data Analytics in Agriculture: Benefits and Challenges. IEEE Internet Things J. 2018, 5, 3758-3773. [CrossRef]

214. Prost, L.; Berthet, E.T.A.; Cerf, M.; Jeuffroy, M.-H.; Labatut, J.; Meynard, J.-M. Innovative design for agriculture in the move towards sustainability: Scientific challenges. Res. Eng. Des. 2017, 28, 119-129. [CrossRef]

215. Reganold, J.P.; Wachter, J.M. Organic agriculture in the twenty-first century. Nat. Plants 2016, $2,15221$. [CrossRef]

216. Kravchenko, A.N.; Snapp, S.S.; Robertson, G.P. Field-scale experiments reveal persistent yield gaps in low-input and organic cropping systems. Proc. Natl. Acad. Sci. USA 2017, 114, 926-931. [CrossRef]

217. De Ponti, T.; Rijk, B.; Van Ittersum, M.K. The crop yield gap between organic and conventional agriculture. Agric. Syst. 2012, 108, 1-9. [CrossRef] 
218. Sharpe, R.M.; Gustafson, L.; Hewitt, S.; Kilian, B.; Crabb, J.; Hendrickson, C.; Jiwan, D.; Andrews, P.; Dhingra, A. Concomitant phytonutrient and transcriptome analysis of mature fruit and leaf tissues of tomato (Solanum lycopersicum L. Cv. Oregon Spring) grown using organic and conventional fertilizer. PLoS ONE 2020, 15, e0227429. [CrossRef]

219. Zheng, H.; Wang, X.; Chen, L.; Wang, Z.; Xia, Y.; Zhang, Y.; Wang, H.; Luo, X.; Xing, B. Enhanced growth of halophyte plants in biochar-amended coastal soil: Roles of nutrient availability and rhizosphere microbial modulation. Plant. Cell Environ. 2018, 41, 517-532. [CrossRef] [PubMed]

220. Laird, D.A.; Novak, J.M.; Collins, H.P.; Ippolito, J.A.; Karlen, D.L.; Lentz, R.D.; Sistani, K.R.; Spokas, K.; Van Pelt, R.S. Multi-year and multi-location soil quality and crop biomass yield responses to hardwood fast pyrolysis biochar. Geoderma 2017, 289, 46-53. [CrossRef]

221. Knapp, S.; van der Heijden, M.G.A. A global meta-analysis of yield stability in organic and conservation agriculture. Nat. Commun. 2018, 9, 1-9. [CrossRef]

222. Biederman, L.A.; Harpole, W.S. Biochar and its effects on plant productivity and nutrient cycling: A meta-analysis. GCB Bioenergy 2013, 5, 202-214. [CrossRef]

223. Amoakwah, E.; Arthur, E.; Frimpong, K.A.; Parikh, S.J.; Islam, R. Soil organic carbon storage and quality are impacted by corn cob biochar application on a tropical sandy loam. J. Soils Sediments 2020, 20, 1960-1969. [CrossRef]

224. Fryda, L.; Visser, R.; Schmidt, J. Biochar Replaces Peat in Horticulture: Environmental Impact Assessment of Combined Biochar \& Bioenergy Production. Detritus 2019, 5, 132-149. [CrossRef]

225. Thi Thu Hien, T.; Shinogi, Y.; Taniguchi, T.; Hien, T.T.T.; Shinogi, Y.; Taniguchi, T. The Different Expressions of Draft Cherry Tomato Growth, Yield, Quality under Bamboo and Rice Husk Biochars Application to Clay Loamy Soil. Agric. Sci. 2017, 08, 934-948. [CrossRef]

226. Woldetsadik, D.; Drechsel, P.; Marschner, B.; Itanna, F.; Gebrekidan, H. Effect of biochar derived from faecal matter on yield and nutrient content of lettuce (Lactuca sativa) in two contrasting soils. Environ. Syst. Res. 2018, 6, 2. [CrossRef]

227. Liu, B.; Cai, Z.; Zhang, Y.; Liu, G.; Luo, X.; Zheng, H. Comparison of efficacies of peanut shell biochar and biochar-based compost on two leafy vegetable productivity in an infertile land. Chemosphere 2019, 224, 151-161. [CrossRef]

228. Velez, T.I.; Moonilall, N.I.; Reed, S.; Jayachandran, K.; Scinto, L.J. Impact of melaleuca quinquenervia biochar on phaseolus vulgaris growth, soil nutrients, and microbial gas flux. J. Environ. Qual. 2018, 47, 1487-1495. [CrossRef]

229. Alotaibi, K.D.; Schoenau, J.J. Addition of Biochar to a Sandy Desert Soil: Effect on Crop Growth, Water Retention and Selected Properties. Agronomy 2019, 9, 327. [CrossRef]

230. Nzediegwu, C.; Prasher, S.; Elsayed, E.; Dhiman, J.; Mawof, A.; Patel, R. Effect of Biochar on the Yield of Potatoes Cultivated Under Wastewater Irrigation for Two Seasons. J. Soil Sci. Plant Nutr. 2019, 19, 865-877. [CrossRef]

231. Griffin, D.E.; Wang, D.; Parikh, S.J.; Scow, K.M. Short-lived effects of walnut shell biochar on soils and crop yields in a long-term field experiment. Agric. Ecosyst. Environ. 2017, 236, 21-29. [CrossRef]

232. Li, S.; Shangguan, Z. Positive effects of apple branch biochar on wheat yield only appear at a low application rate, regardless of nitrogen and water conditions. J. Soils Sediments 2018, 18, 3235-3243. [CrossRef]

233. Faloye, O.T.; Alatise, M.O.; Ajayi, A.E.; Ewulo, B.S. Effects of biochar and inorganic fertiliser applications on growth, yield and water use efficiency of maize under deficit irrigation. Agric. Water Manag. 2019, 217, 165-178. [CrossRef]

234. Kang, S.-W.; Kim, S.-H.; Park, J.-H.; Seo, D.-C.; Ok, Y.S.; Cho, J.-S. Effect of biochar derived from barley straw on soil physicochemical properties, crop growth, and nitrous oxide emission in an upland field in South Korea. Environ. Sci. Pollut. Res. 2018, 25, 25813-25821. [CrossRef]

235. Munda, S.; Bhaduri, D.; Mohanty, S.; Chatterjee, D.; Tripathi, R.; Shahid, M.; Kumar, U.; Bhattacharyya, P.; Kumar, A.; Adak, T.; et al. Dynamics of soil organic carbon mineralization and C fractions in paddy soil on application of rice husk biochar. Biomass Bioenergy 2018, 115, 1-9. [CrossRef]

236. Faria, W.M.; de Figueiredo, C.C.; Coser, T.R.; Vale, A.T.; Schneider, B.G. Is sewage sludge biochar capable of replacing inorganic fertilizers for corn production? Evidence from a two-year field experiment. Arch. Agron. Soil Sci. 2018, 64, 505-519. [CrossRef] 
237. Sarma, B.; Borkotoki, B.; Narzari, R.; Kataki, R.; Gogoi, N. Organic amendments: Effect on carbon mineralization and crop productivity in acidic soil. J. Clean. Prod. 2017, 152, 157-166. [CrossRef]

238. Takaragawa, H.; Yabuta, S.; Watanabe, K.; Kawamitsu, Y. Effects of Application of Bagasse- and Sunflower Residue-derived Biochar to Soil on Growth and Yield of Oilseed Sunflower. Trop. Agric. Dev. 2017, 61, 32-39. [CrossRef]

239. Hood-Nowotny, R.; Watzinger, A.; Wawra, A.; Soja, G. The Impact of Biochar Incorporation on Inorganic Nitrogen Fertilizer Plant Uptake; An Opportunity for Carbon Sequestration in Temperate Agriculture. Geosciences 2018, 8, 420. [CrossRef]

240. Boersma, M.; Wrobel-Tobiszewska, A.; Murphy, L.; Eyles, A. Impact of biochar application on the productivity of a temperate vegetable cropping system. N. Z. J. Crop Hortic. Sci. 2017, 45, 277-288. [CrossRef]

241. Artiola, J.F.; Rasmussen, C.; Freitas, R. Effects of a Biochar-Amended Alkaline Soil on the Growth of Romaine Lettuce and Bermudagrass. Soil Sci. 2012, 177, 561-570. [CrossRef]

242. Azeem, M.; Hayat, R.; Hussain, Q.; Ahmed, M.; Pan, G.; Ibrahim Tahir, M.; Imran, M.; Irfan, M.; Mehmood-ul-Hassan. Biochar improves soil quality and $\mathrm{N}_{2}$-fixation and reduces net ecosystem $\mathrm{CO}_{2}$ exchange in a dryland legume-cereal cropping system. Soil Tillage Res. 2019, 186, 172-182. [CrossRef]

243. Rezaie, N.; Razzaghi, F.; Sepaskhah, A.R. Different Levels of Irrigation Water Salinity and Biochar Influence on Faba Bean Yield, Water Productivity, and Ions Uptake. Commun. Soil Sci. Plant Anal. 2019, 50, 611-626. [CrossRef]

244. El-Naggar, A.; El-Naggar, A.H.; Shaheen, S.M.; Sarkar, B.; Chang, S.X.; Tsang, D.C.W.; Rinklebe, J.; Ok, Y.S. Biochar composition-dependent impacts on soil nutrient release, carbon mineralization, and potential environmental risk: A review. J. Environ. Manag. 2019, 241, 458-467. [CrossRef]

245. Lima, I.M.; White, P.M., Jr. Sugarcane bagasse and leaf residue biochars as soil amendment for increased sugar and cane yields. Int. Sugar J. 2017, 119, 382-390.

246. Jay, C.N.; Fitzgerald, J.D.; Hipps, N.A.; Atkinson, C.J. Why short-term biochar application has no yield benefits: Evidence from three field-grown crops. Soil Use Manag. 2015, 31, 241-250. [CrossRef]

247. Ogbe, V.B.; Jayeoba, O.J.; Amana, S.M. Effect of Rice Husk as an Amendment On The Physico-Chemical Properties of Sandy-Loam Soil In Lafia, Southern-Guinea Savannah, Nigeria. Prod. Agric. Technol. 2015, 11,44-55. [CrossRef]

248. Farrell, M.; Macdonald, L.M.; Butler, G.; Chirino-Valle, I.; Condron, L.M. Biochar and fertiliser applications influence phosphorus fractionation and wheat yield. Biol. Fertil. Soils 2014, 50, 169-178. [CrossRef]

249. Marra, R.; Vinale, F.; Cesarano, G.; Lombardi, N.; d’Errico, G.; Crasto, A.; Mazzei, P.; Piccolo, A.; Incerti, G.; Woo, S.L.; et al. Biochars from olive mill waste have contrasting effects on plants, fungi and phytoparasitic nematodes. PLoS ONE 2018, 13, e0198728. [CrossRef] [PubMed]

250. Intani, K.; Latif, S.; Islam, M.; Müller, J. Phytotoxicity of Corncob Biochar before and after Heat Treatment and Washing. Sustainability 2018, 11, 30. [CrossRef]

251. Paetsch, L.; Mueller, C.W.; Kögel-Knabner, I.; Von Lützow, M.; Girardin, C.; Rumpel, C. Effect of in-situ aged and fresh biochar on soil hydraulic conditions and microbial $\mathrm{C}$ use under drought conditions. Sci. Rep. 2018, 8. [CrossRef] [PubMed]

252. Hersh, B.; Mirkouei, A.; Sessions, J.; Rezaie, B.; You, Y. A review and future directions on enhancing sustainability benefits across food-energy-water systems: The potential role of biochar-derived products. AIMS Environ. Sci. 2019, 6, 379-416. [CrossRef]

253. Wang, F.; Liu, Y.; Li, X.; Liu, F. Effects of Biochar Amendment, $\mathrm{CO}_{2}$ Elevation and Drought on Leaf Gas Exchange, Biomass Production and Water Use Efficiency in Maize. Pak. J. Bot. 2018, 50, 1347-1353.

254. Rajapaksha, A.U.; Chen, S.S.; Tsang, D.C.W.; Zhang, M.; Vithanage, M.; Mandal, S.; Gao, B.; Bolan, N.S.; Ok, Y.S. Engineered/designer biochar for contaminant removal/immobilization from soil and water: Potential and implication of biochar modification. Chemosphere 2016, 148, 276-291. [CrossRef]

255. Ok, Y.S.; Tsang, D.C.W.; Bolan, N.; Novak, J.M. Biochar from Biomass and Waste: Fundamentals and Applications; Elsevier: Amsterdam, The Netherlands, 2018.

256. Novak, J.M.; Johnson, M.G.; Spokas, K.A. Concentration and Release of Phosphorus and Potassium From Lignocellulosic- and Manure-Based Biochars for Fertilizer Reuse. Front. Sustain. Food Syst. 2018, 2, 54. [CrossRef] 
257. Al-Wabel, M.I.; Hussain, Q.; Usman, A.R.A.; Ahmad, M.; Abduljabbar, A.; Sallam, A.S.; Ok, Y.S. Impact of biochar properties on soil conditions and agricultural sustainability: A review. Land Degrad. Dev. 2018, 29, 2124-2161. [CrossRef]

258. Nair, A.; Lang, K.; Snyder, D. Impact of Biochar and Fertility Management on Potato Production; Iowa State University Research and Demostration Farms Progress Reports; 2018. Available online: https:/lib.dr.iastate. edu/farmprogressreports/vol2017/iss1/71/ (accessed on 21 March 2020).

259. Youssef, M.; Al-Easily, I.A.S.; Nawar, D.A.S. Impact of Biochar Addition on Productivity and Tubers Quality of Some Potato Cultivars Under Sandy Soil Conditions. Egypt. J. Hortic. 2017, 44, 199-217. [CrossRef]

260. Gámiz, B.; Velarde, P.; Spokas, K.A.; Celis, R.; Cox, L. Changes in sorption and bioavailability of herbicides in soil amended with fresh and aged biochar. Geoderma 2019, 337, 341-349. [CrossRef]

(C) 2020 by the authors. Licensee MDPI, Basel, Switzerland. This article is an open access article distributed under the terms and conditions of the Creative Commons Attribution (CC BY) license (http://creativecommons.org/licenses/by/4.0/). 